\title{
Ergonomic Assessment and Design of the Tower Crane Cabin Based on Anthropometric Dimensions of Iranian Operators
}

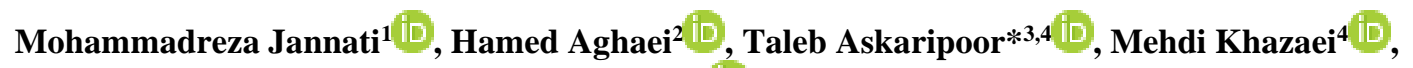 \\ Ehsan Bayat Khalaji ${ }^{4}$ (D), Elahe Kazemi ${ }^{4}$
}

1. Student Research Committee, Semnan University of Medical Sciences, Semnan, Iran.

2. Assistant Professor, Department of Occupational Health Engineering, School of Health, Arak University of Medical Sciences, Arak, Iran

3. Assistant Professor, Research Center for Health Sciences and Technologies, Semnan University of Medical Sciences, Semnan, Iran

4. Department of Occupational Health and Safety Engineering, Faculty of Health, Semnan University of Medical Sciences, Semnan, Iran

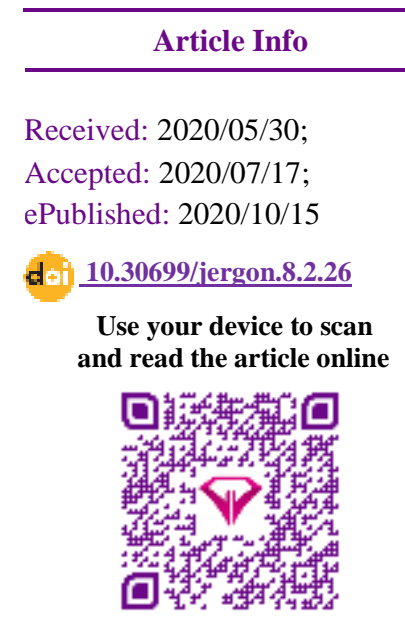

Corresponding Author Taleb Askaripoor Assistant Professor, Research Center for Health Sciences and Technologies, Semnan University of Medical Sciences, Semnan, Iran

Tel: 09126961728

Email:

askaripoor@semums.ac.ir

\begin{abstract}
Background and Objectives: Despite the main role of cranes in advancing construction operations, however, accidents and occupational injuries resulting from their activities have become a critical issue. Recent evidence suggests that the cause of these problems may be associated with the absence of design of the interior space of the crane cabin, and the tasks of the operators, based on ergonomic principles. This study was conducted to assess the ergonomic risk of the tower crane operator's activities and redesigning the dimensions and interior space of these cranes, based on the anthropometric dimensions of Iranian operators.
\end{abstract}

Methods: In this descriptive cross-sectional study, 30 male tower crane operators working on three major construction projects in Tehran were investigated. Initially, a multi-step approach was applied to define the problem, including: observing the working statuses, interviewing operators, Nordic Musculoskeletal Disorder Questionnaire, and rapid upper limb assessment (RULA) method. Then, using anthropometric data, the dimensions and interior space of the crane chamber were redesigned.

Results: The results of the rapid upper limb assessment method showed that the activities of tower crane operators were at high and very high-risk levels. Also, 85\% and $38.5 \%$ of these people reported pain and discomfort in one of the nine areas of their body in the last 12 months and 7 days, respectively. In this study, the dimensions of the interior space of the redesigned tower crane cabin were obtained $160.8 \times 144.1 \times 199.7$.

Conclusion: Based on the results of the study, it can be concluded that the current interior design of the tower crane cabin does not fulfill the needs of the operators. Hence, redesigning it appears essential to enhance human-machine compatibility, improve safety and productivity, and prevent musculoskeletal disorders (MSD).

Keywords: Tower Crane, Rapid upper limb assessment (RULA), Nordic Questionnaire, Anthropometry

Copyright (C) 2020, This is an original open-access article distributed under the terms of the Creative Commons Attribution-noncommercial 4.0 International License which permits copy and redistribute of the material just in noncommercial usages with proper citation.

\section{How to Cite This Article:}

Jannati M, Aghaei H, Askaripoor T, Khazaei M, Bayat Khalaji E, Kazemi E. Ergonomic Assessment and Design of the Tower Crane Cabin Based on Anthropometric Dimensions of Iranian Operators. Iran J Ergon. 2020; 8 (2): 26-38 


\title{
ارزيابى اركونومى و طراحى اتاقى جرثقيل برجى براساس ابعاد آنترويومترى ايراتورهاى ايرانى
}

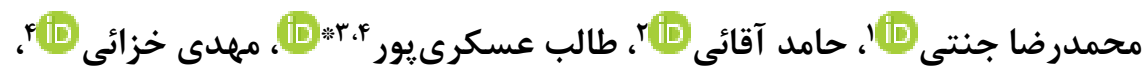

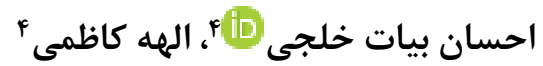

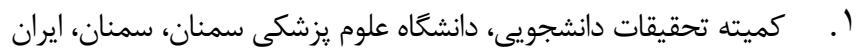

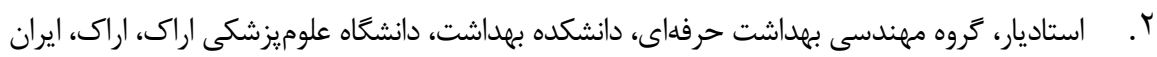

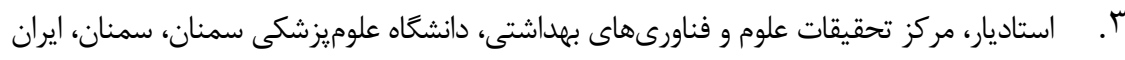

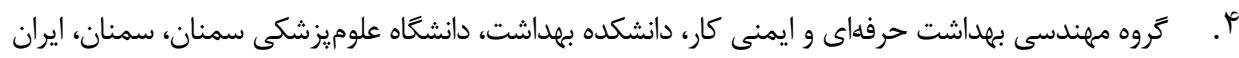

\begin{tabular}{|c|c|}
\hline خلاصه & اطلاعات مقاله \\
\hline 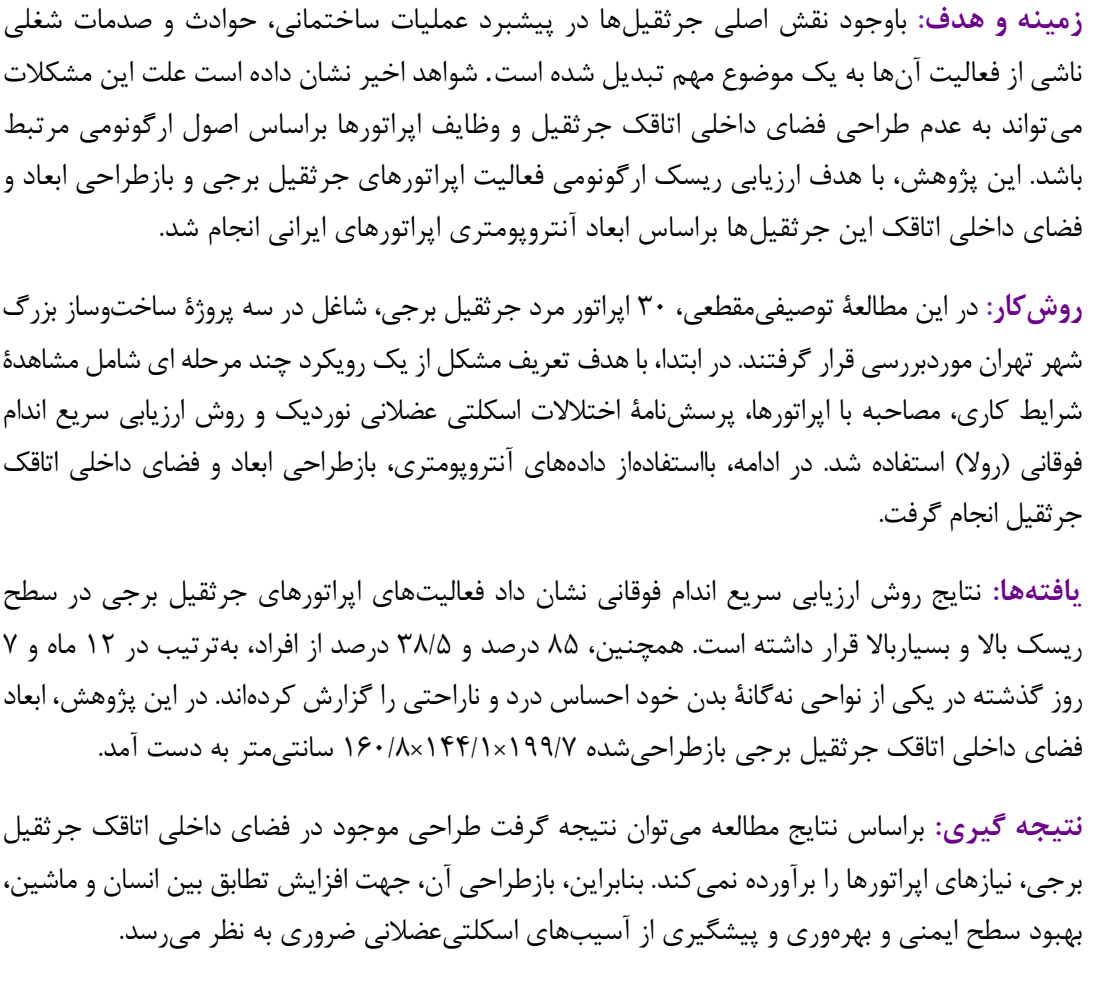 & 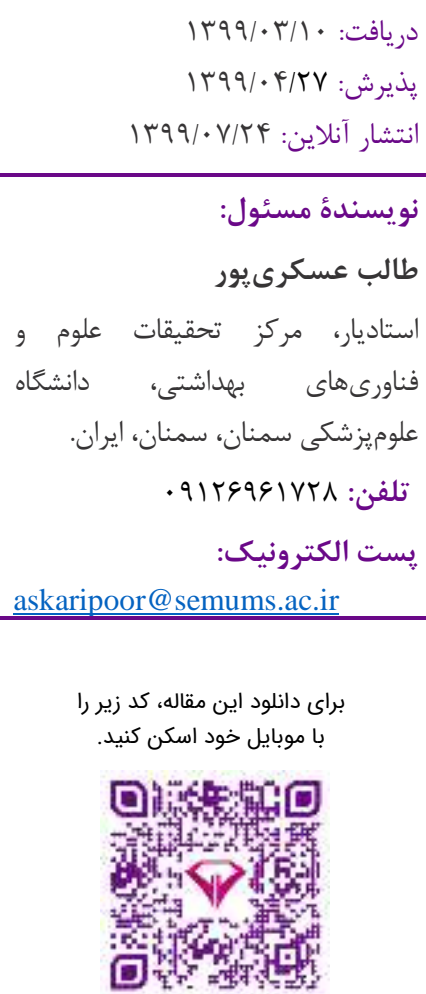 \\
\hline كليدوازهها: جرثقيل برجى، ارزيابى سريع اندام فوقانى (رولا)، يرسشنامئ نورديك، آنترويومترى & \\
\hline
\end{tabular}

مقدمه

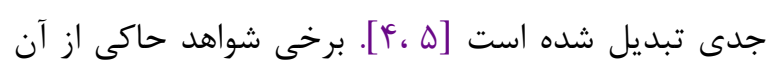

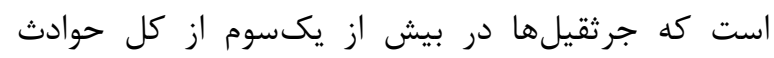

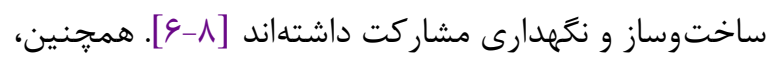

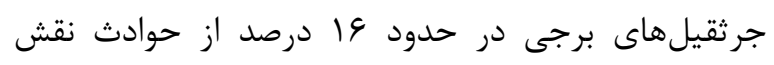

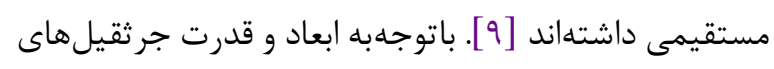

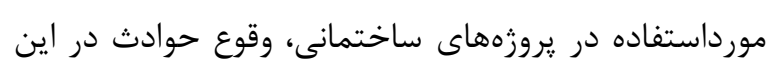

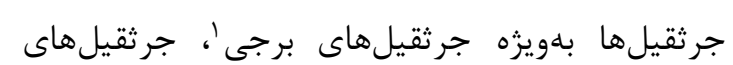
سقفىدروازهاى و جرثقيلهاى موبايل (نصبشده برجن بر وسايل

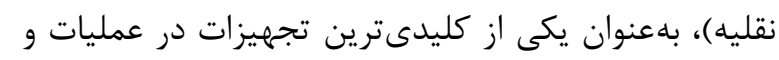

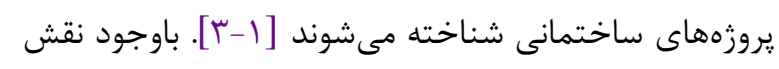

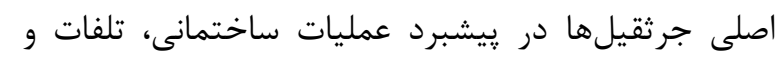

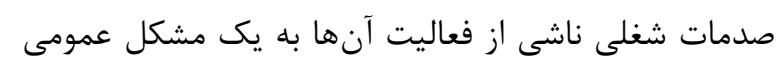


محمدرضا جنتى و همكاران | طراحى اتاقك جرثقيل برجى

ازجمله فاكتورهاى انسانى و ابعاد آنترويومترى استفاده كنند

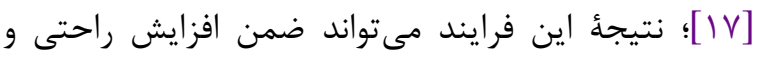

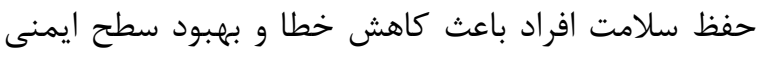

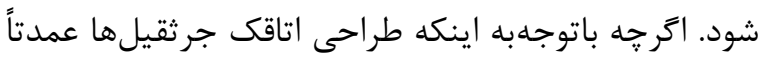

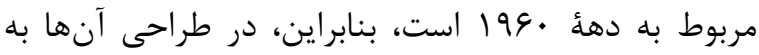
فاكتورهاى انسانى و ابعاد آنترويومترى كمتر توجه قرائ درار

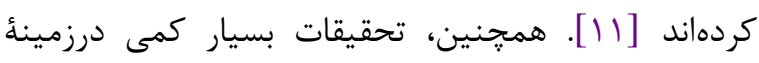
ارزيابى راحتى و تناسب اتاقكها با جمعيت ايراتورها تاكنون در سطح دنيا انجام شده است [1/1]. باتوجهبه وارداتىبودنان اكثر جرثقيل هاى برجى در كشور ما و نبودِ انجام مطالعهاى داى

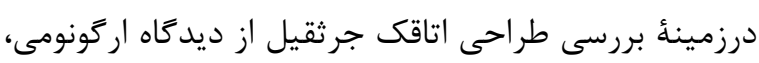

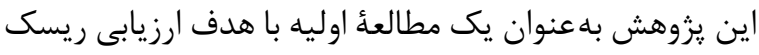

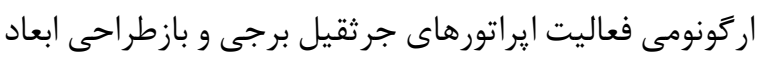

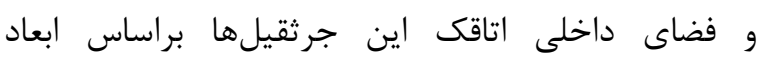

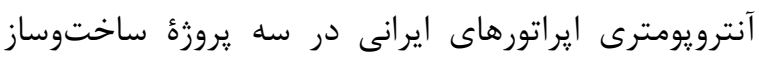
بزرى در شهر تهر ان انجامحرفته است.

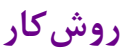

اين يزوهش يك مطالعؤ موردى از نوع توصيفىمقطعى است

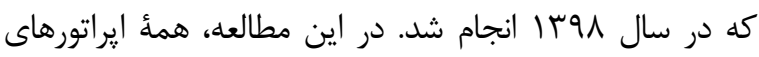
جرثقيل برجى شاغل در سه بروزٔه ساختوساز بزرگ شهر شهر تهران كه شر ايط ورود به مطالعه را داشتند موردبر رسى قرار كر ترفتند. در

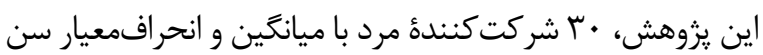

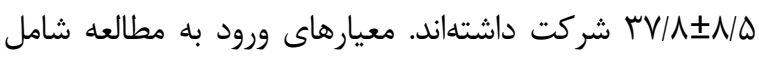

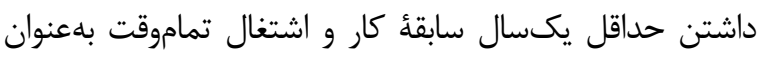
ايراتورهاى جرثقيل برجى و عدم ابتلاى به اختلالات اسكلتى

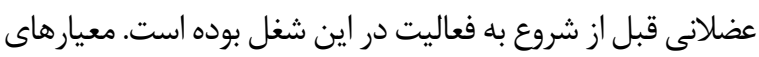

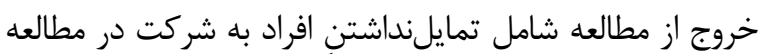

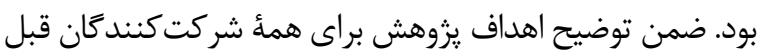

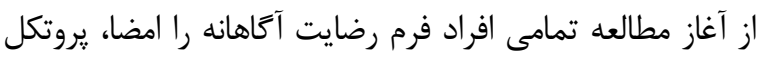
مطالعه با كد IR.SEMUMS.REC.1398.227 به تأييد كميته اخلاق دانشخاه رسيد. در اين يزوهش، با هدف شناسايى و تعريف

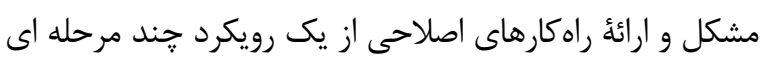

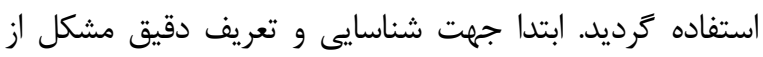
روشهاى جمعآورى دادها همجيون روش مشاهدهاى (مشاهدة وضعيت بدنى و شرايط كارى)، مصاحبه (مصاحبه با ايراتورها و وداي مسئولين مربوطؤ جمعآورى اطلاعات درمورد شرايط كارى و و

5- Bureau of Labor Statistics

6 - Awkward Posture

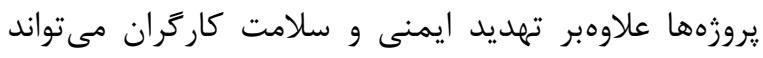

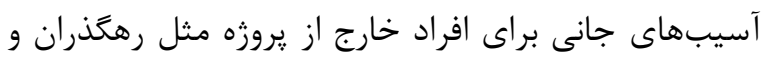

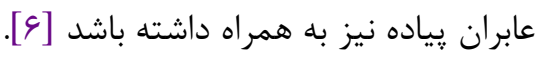

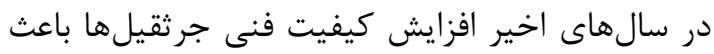
شده متغيرهايى همجون نإيايدارى جرثقيل'، عدم ثبات در

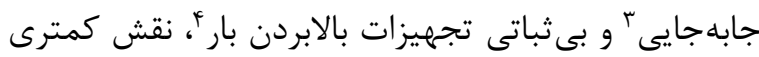

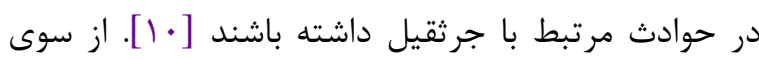

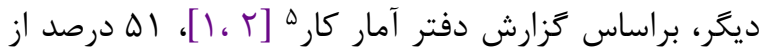
حوادث رخداده در يروزههاى ساختمانى در اثر علل ناشناخته

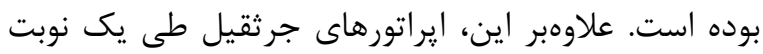

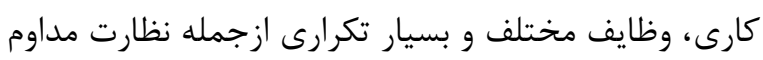
بر فرايند حملونقل، باركيرى و تخلية مصالح ساختمانى،

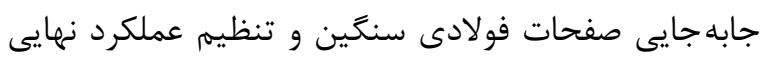

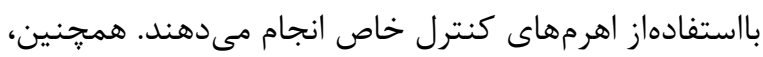

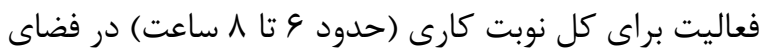

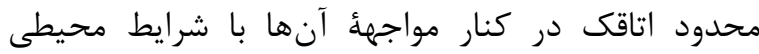

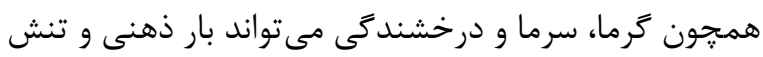

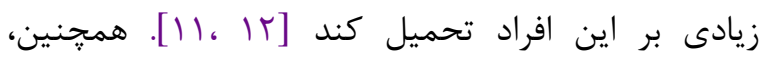
يافتهاى مطالعات ديخر نشان مى دهد در اتاقك جرثقيل،

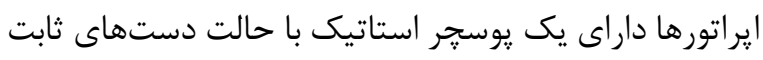

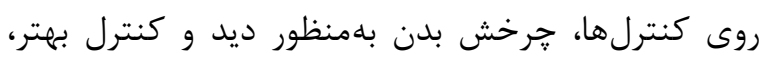
خمش هاى زياد و بعضاً شديد و مواجهه با ارتعاش هستند بند

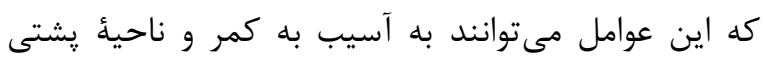

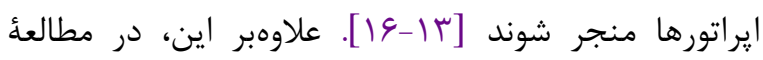
Buchholz وزارش شد كه يوسجرهاى Kittusamy نامناسب' هنگام كار با تجهيزات تخصصى و سنكين

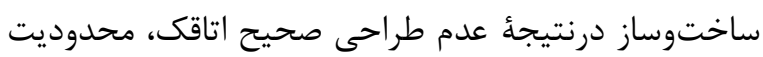
فضاى داخلى اتاقك، ديد محدود، نيروى زياد جهرت جابهجايى اهرمها و طراحى نامناسب صندلى نها بوده است

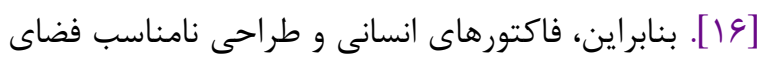
اتاقى جرثقيل مىتواند از علل مرتبط با وقوع حوادث و واتئ مشكلات مرتبط با ايمنى و سلامت كاركنان در صنان صانعت ساختوساز در نظر كرفته شود و بررسى جامع اين موضوع و ودان

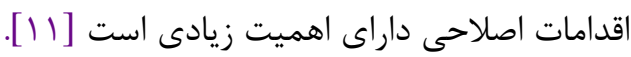
براساس شواهد موجود جنانجه يك محصول براى إن ياسخكَويى به نيازهاى گروه خاصى از كاربران طراحى شده

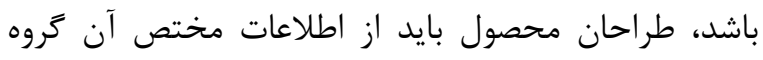

2 - Crane instability

3 - Jib instability

4 - Hoisting equipment instability 


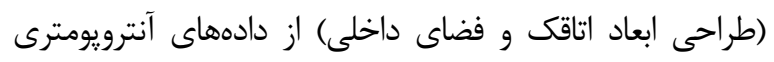

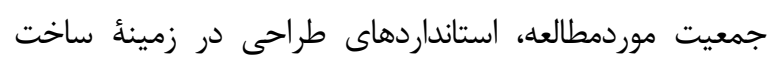

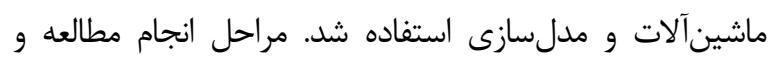

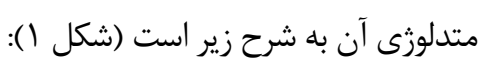

وضعيتهاى بدنى و بررسى مستندات)، يرسشنامئ استاندارد

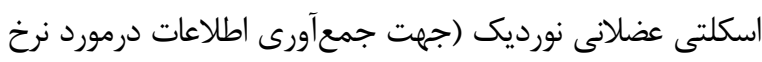

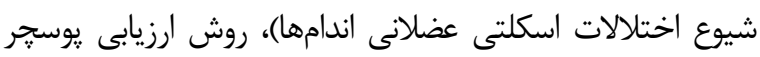

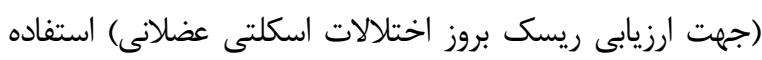

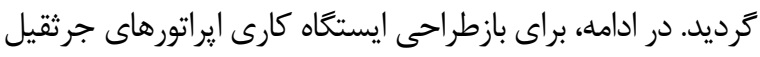

\section{بر رسى وضعيت موجود}

مشاهده، مصاحبه و بررسى مستندات، ارزيابى وضعيتهاى كارى باستفادهاز روش ارزيابى سريع اندام فوقانى (RULA) و بررسى ميزان شيوع

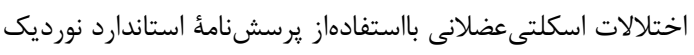

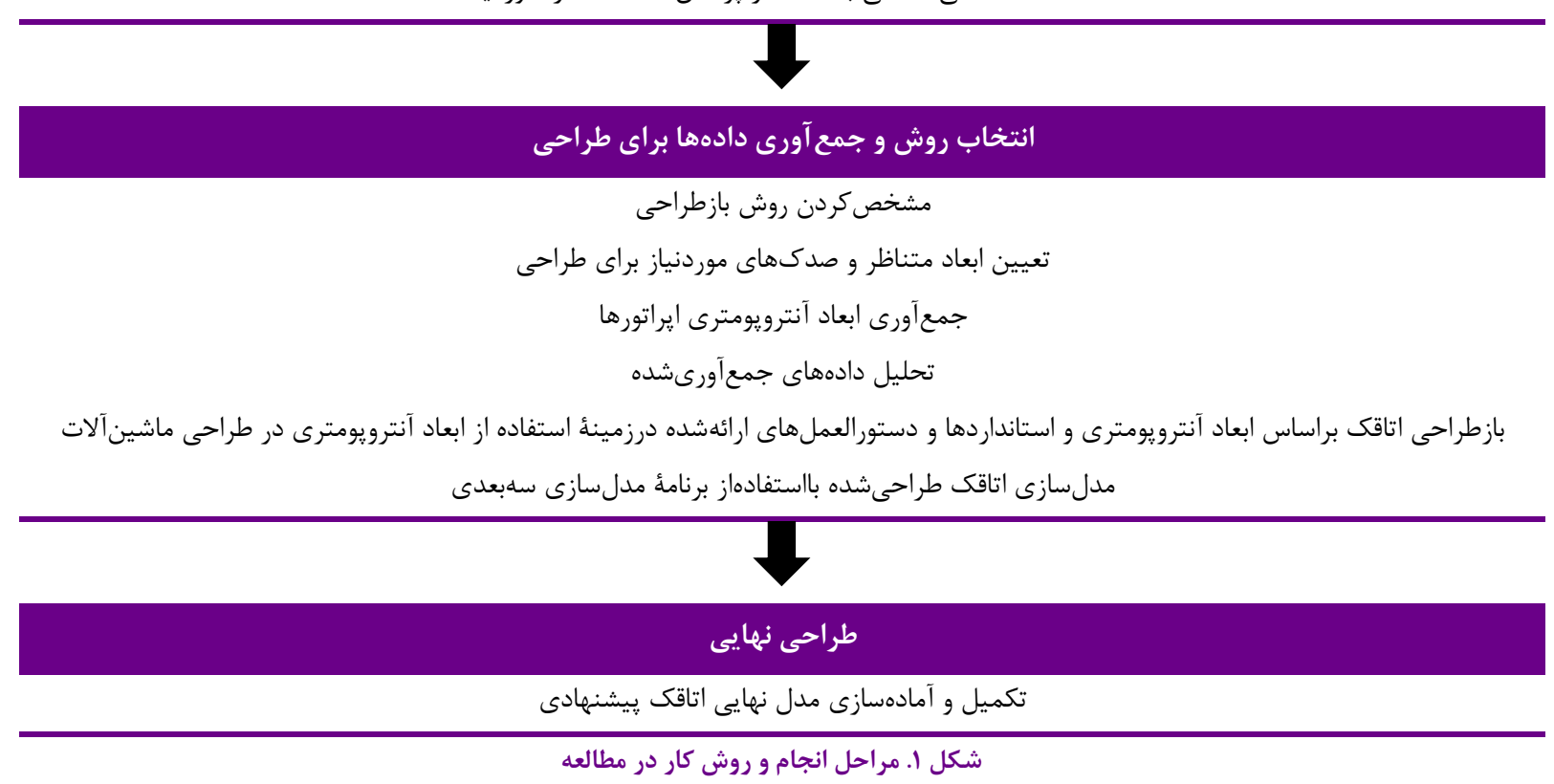

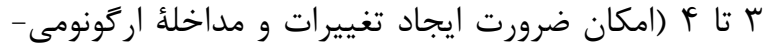

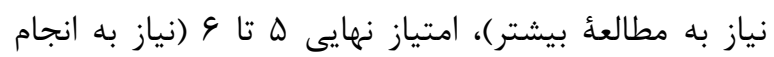

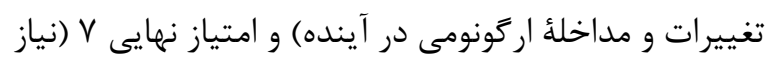

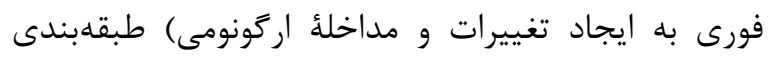

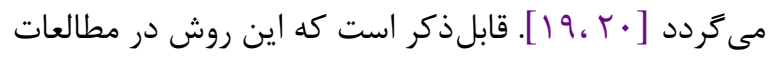

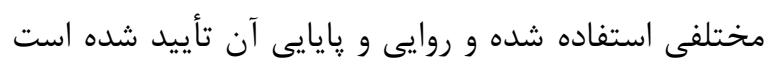

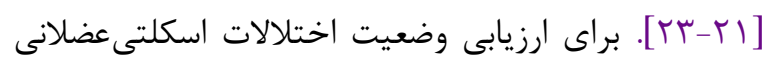
در بين ايراتورهاى موردمطالعه از يرسشنامهُ عمومى نورديك رئ

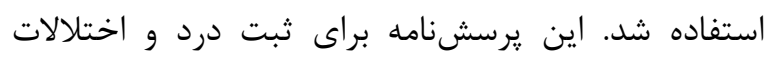

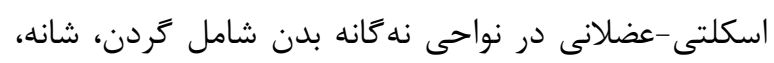

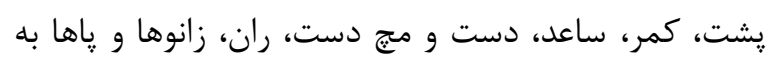

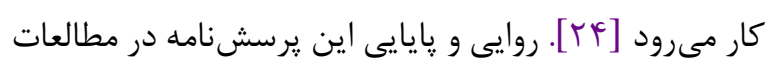

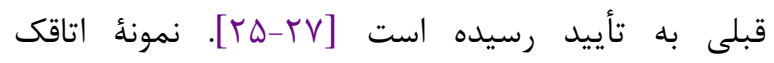

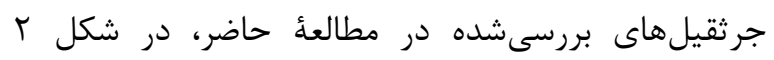
نمايش داده شده است.

\section{مر حلة اول: بررسى وضعيت موجود}

براى بهدستآوردن تصويرى دقيق از وضعيت و مشكلات موجود، تعيين نقاط بحرانى و لزوم انجام مداخله در كنار

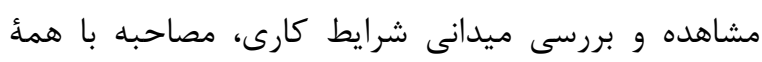

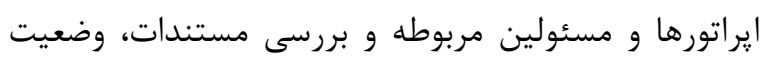
كارى ايراتورهاى جرثقيل در تمام فعاليتهاى مربوط به اين مين مئن شغل باستفادهاز روش ارزيابى يوسجر سريع اندام فوقانى رولا (RULA ) اسكلتى عضلانى باستفادهاز : يرسشنامة استاندارد نورديك إنى مورد ارزيابى قرار گرفت. روش ارزيابى يوسجر سريع اندام

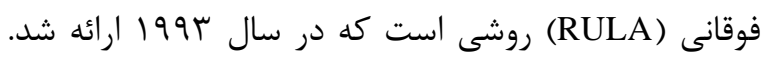
در اين روش، وضعيت بدنى، نيروى كارى به كاررفته و فعاليت

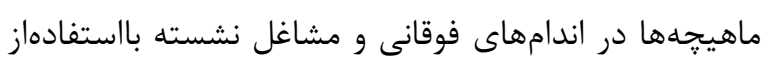
امتيازبندى عددى مورد ارزيابى قرار مى گيرد. امتياز نهايى

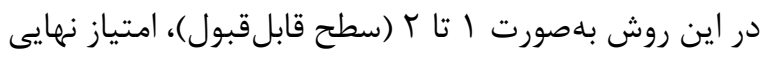

\footnotetext{
${ }^{7}$ Rapid Upper Limb Assessment (RULA)
} 


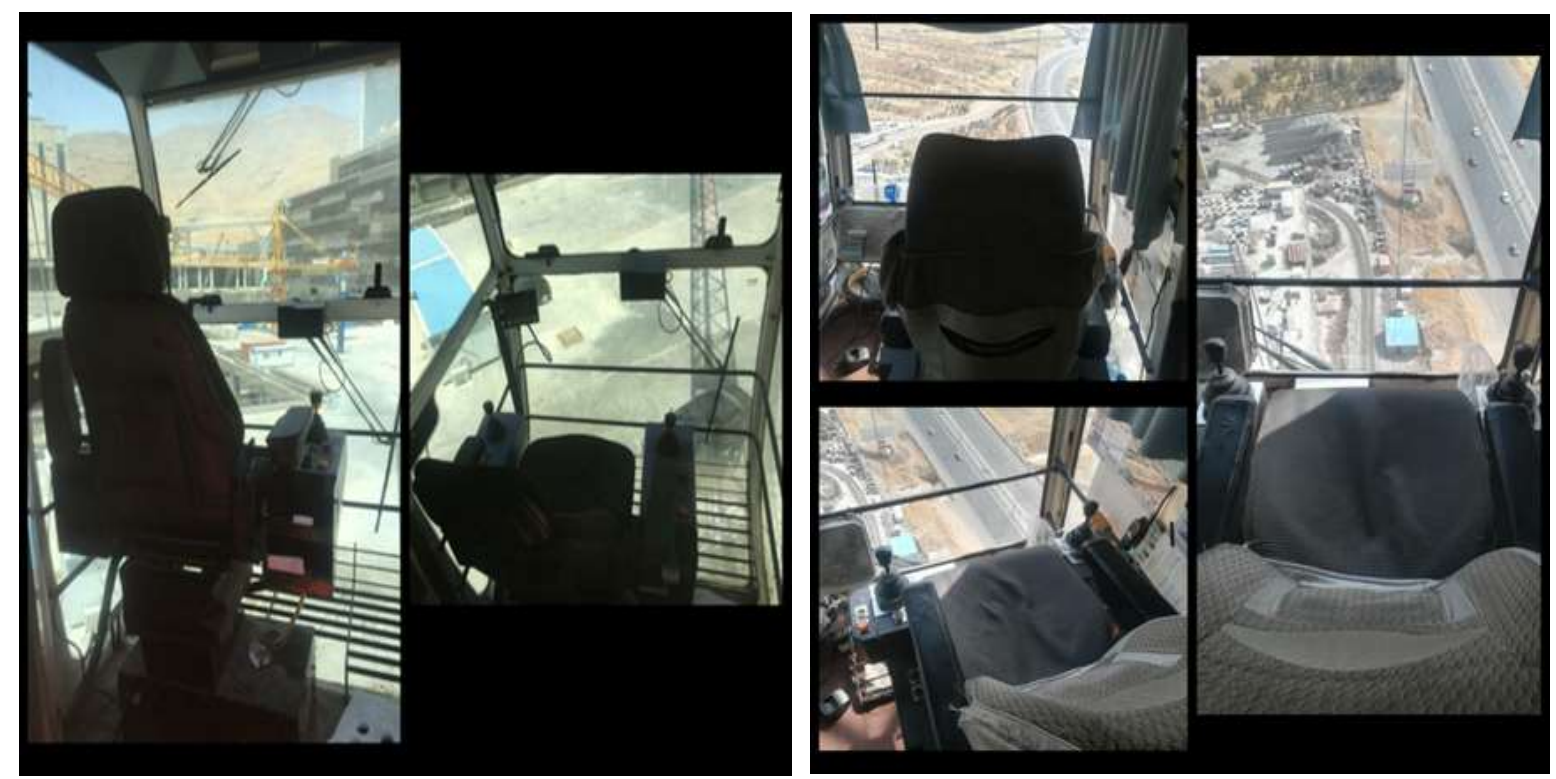

شكل r. فضاى داخلى اتاقك جرثقيل هاى موردبر رسى در مطالعهُ حاضر

مرحلة سوم: بازطراحى اتاقى جرثقيل برجى براساس ابعاد آنترويومترى جمعيت موردمطالعه سيه

در اين مرحله براى بازطراحى اتاقى جرثقيل برجى

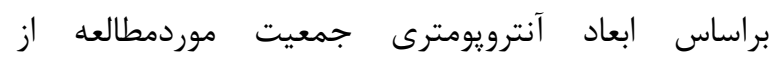

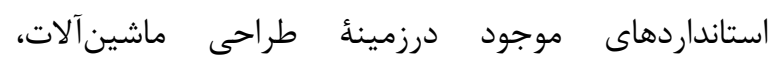

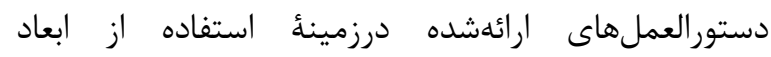

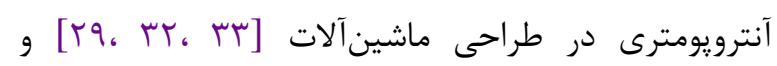

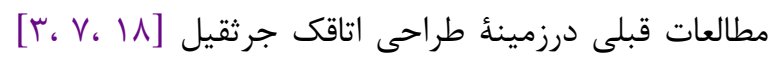

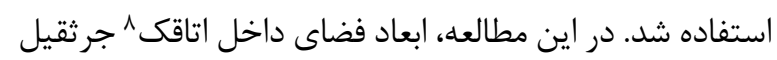

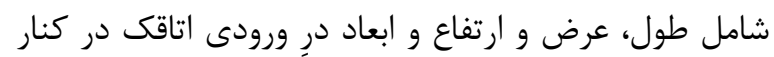

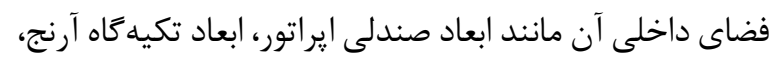

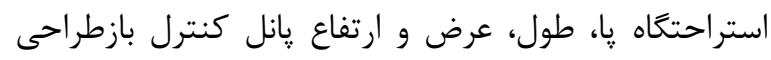

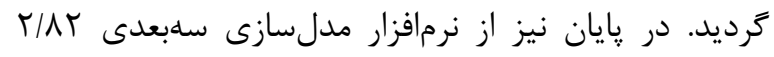
Blender براى شبيهسازى طراحى انجامشده استفاده كرديد.

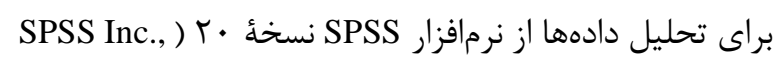
(Chicago, Ill., USA

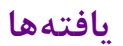

نتايج حاصل از روش ارزيابى يوسجر رولا (RULA) در بررسى سه وظيفة اصلى ايراتورهاى جرثقيل برجى شامل ردابل

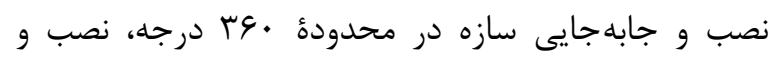

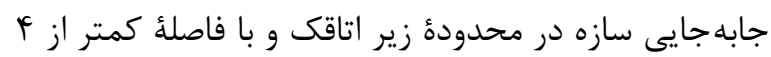

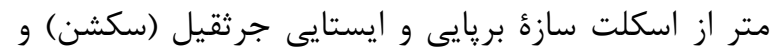

مرحلة دوم: تعيين و جمع آورى دادههاى آنترويومترى جمعيت موردمطالعه

در اين مطالعه با هدف طراحى ابعاد و فضاى داخلى اتاقك

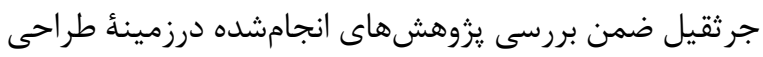

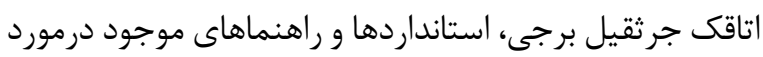

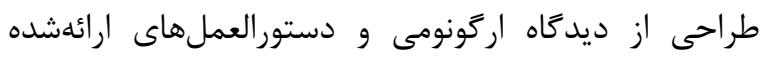

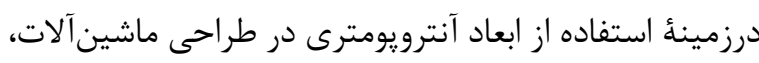

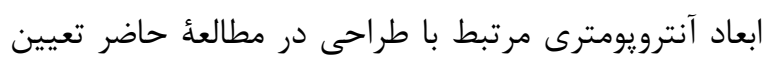

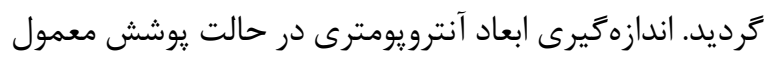

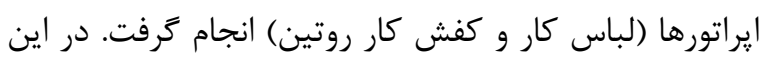

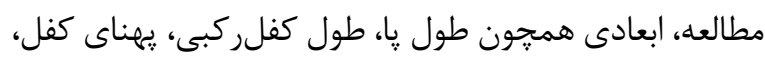
طول بازو، عرض شانه، طول ساعد، ارتفاع ركبى، ارتفاع آرنج

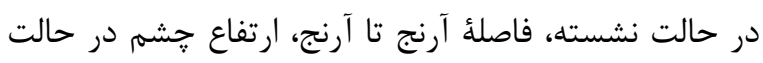

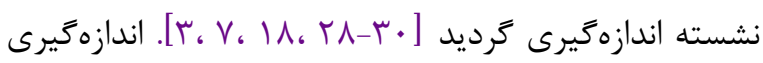

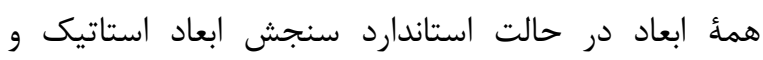

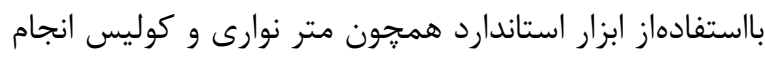

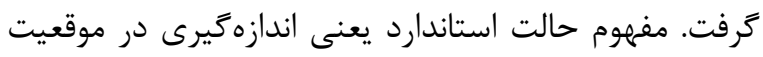

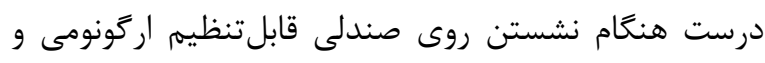

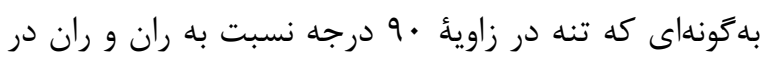

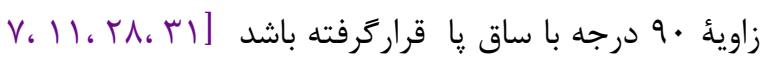

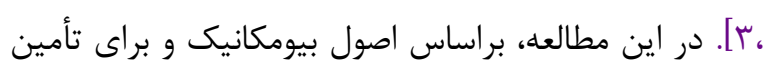

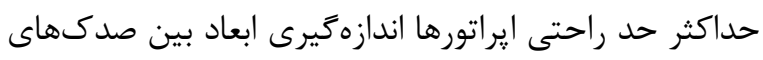

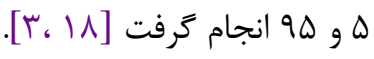

\footnotetext{
${ }^{8}$ Dimensions of the interior space
} 


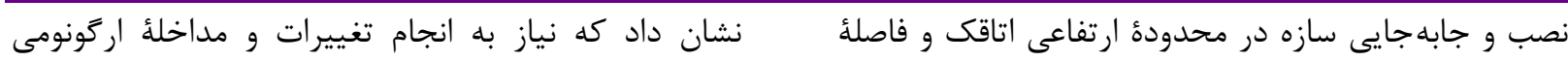

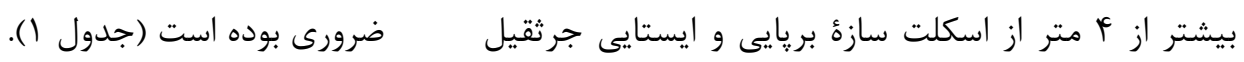

جدول ا. نتايج ارزيابى وضعيتهاى كارى به روش رولا (RULA)

\begin{tabular}{|c|c|c|c|c|c|c|}
\hline \multicolumn{3}{|c|}{ اندام جب } & \multicolumn{3}{|c|}{ اندام راست } & \multirow[b]{2}{*}{ نوع فعاليت } \\
\hline اقدام عملى موردنياز & ريسك & نهايى امتياز & اقدام عملى موردنياز & 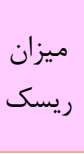 & 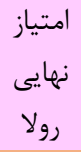 & \\
\hline 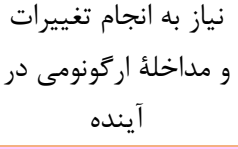 & بالا & 9 & و مياز به انجام تغييرات & بالا & 9 & نصب و جابه جايى سازه و بار در محدودة •وب؟ \\
\hline$"$ & بالا & $\Delta$ & $"$ & بالا & $\Delta$ & 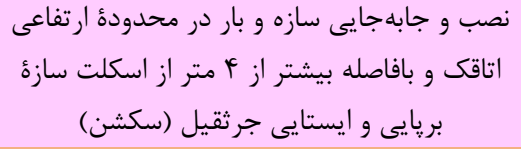 \\
\hline تغيير فورى به ايجاد مداخله & بسالا & V & تياز فورى به ايجاد & بالا & V & 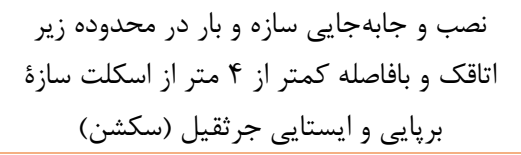 \\
\hline
\end{tabular}

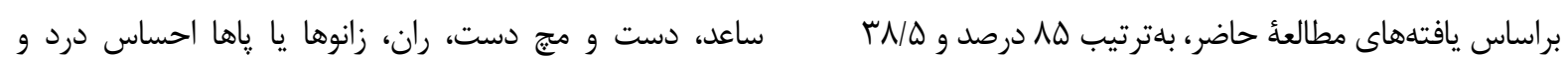

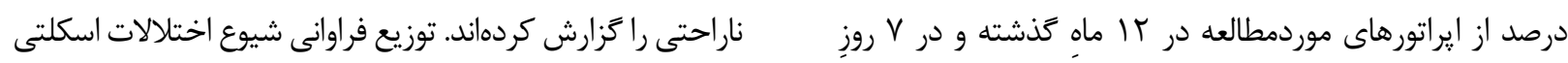

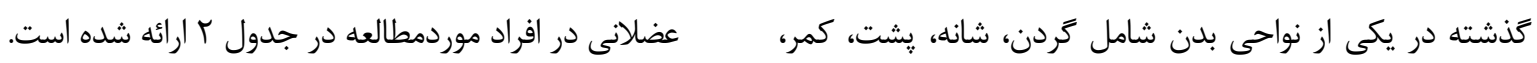
جدول r. توزيع فر اوانى شيوع اختلالات اسكلتى عضلانى براساس يرسشنامهُ نورديك

\begin{tabular}{|c|c|c|c|}
\hline \multicolumn{3}{|c|}{ فراوانى (درصد) } & \multirow[b]{2}{*}{ اندام } \\
\hline بازماندكى از كار ناشى از درد و ناراحتى & احساس درد و ناراحتى در \ روز گذشته & 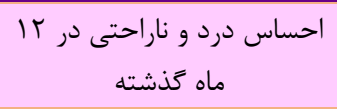 & \\
\hline- & - & $r \pi / l$ & كردن \\
\hline- & - & $V / V$ & شانه \\
\hline- & - & $V / V$ & ساعد \\
\hline- & $V / V$ & $\mid Q / F$ & دست و مجج \\
\hline- & $V / V$ & rN/D & يشت \\
\hline$V / V$ & $\mid Q / F$ & $41 / 0$ & كمر \\
\hline$r M / l$ & - & - & يك يا هر دو \\
\hline- & $\mid \Delta / F$ & $\Gamma N / \Delta$ & يك زيا هردو \\
\hline$V / V$ & - & - & و يك يا هردو يا \\
\hline
\end{tabular}

گرديد. ميانگين، انحرافمعيار و صدكهاى ه و هو اين ابعاد

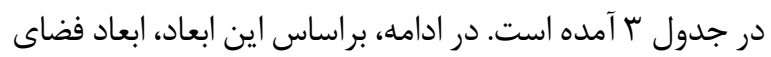

در اين مطالعه با هدف طراحى اتاقى جرثقيل، ابعاد

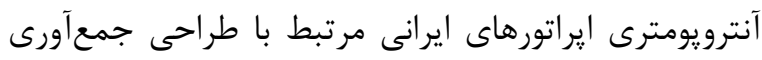


محمدرضا جنتى و همكاران | طراحى اناقك جرثقيل برجى إنى

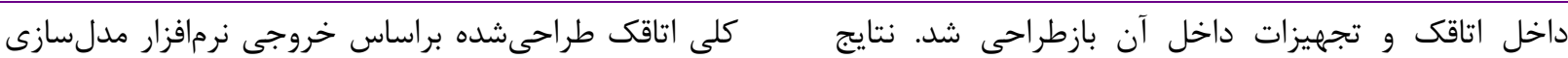

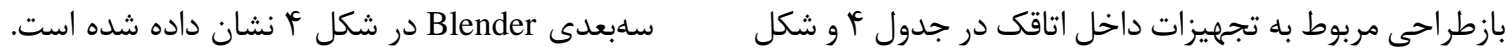

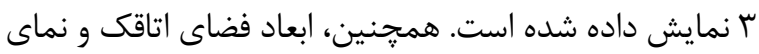

جدول r. ميانكَين، انحرافمعيار و صدىهاى ه و هو ابعاد آنترويومترى جمعيت موردمطالعه

\section{ابعاد آنتروبومترى}

ن

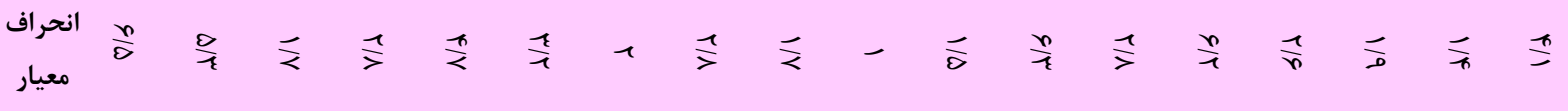

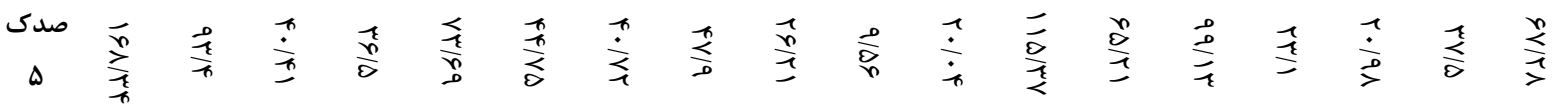

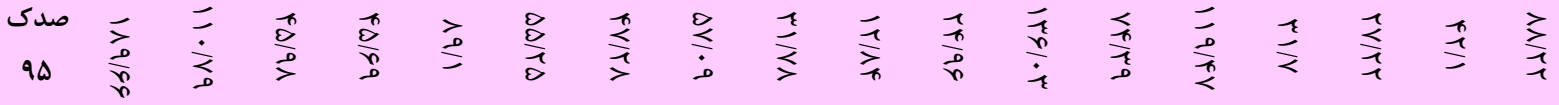

جدول F. نتايج طراحى مربوط به تجهيزات فضاى داخلى اتاقك برمبناى ابعاد آنترويومترى جمعيت موردمطالعه

\begin{tabular}{|c|c|c|}
\hline معيار طراحى & مقدار بهدست آمده & بعد مورد طراحى \\
\hline صدى هام تا صدك ه91م ارتفاع ركبى & $F \cdot / V-r V / r$ & ارتفاع صندلى ايراتور از كف اتاقى \\
\hline صدك ه 19م يهناى كفل & $\varphi \Delta / V$ & عرض كف صندلى \\
\hline صدى هام طول كفل ركبى & FF/V & عمق كف صندلى \\
\hline صدى هو1م عرض سر شانه & is & عرض پشتى صندلى \\
\hline صدى هوام ارتفاع شانه از سطح صندلى & $99 / 1$ & 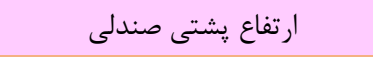 \\
\hline 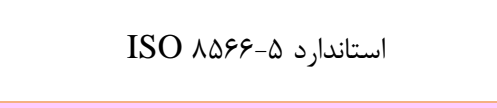 & 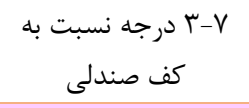 & زاويه پشتى صندلى \\
\hline 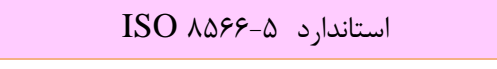 & 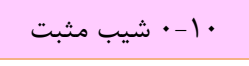 & زاويه نشيمن صندلى \\
\hline صدك هام تاصدى هوام فاصلة سر تا شانه & $r / 1-r / V$ & ارتفاع تكيه كاه سر \\
\hline
\end{tabular}




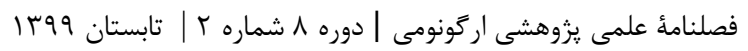

\begin{tabular}{|c|c|c|}
\hline 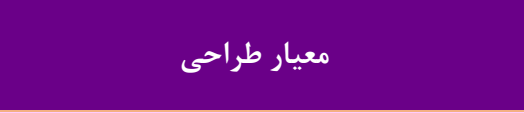 & مقدار بهدست آمده & 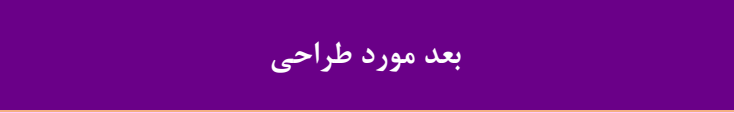 \\
\hline صدك ه91م يهناى سر & $T V / T$ & يهناى تكيه گاه سر \\
\hline صدى هام تاصدى هوام ارتفاع آرنج تا سطح & $T Y / \Delta-T Y / I$ & ارتفاع تكيه كاه آرنج تا سطح صندلى \\
\hline صدى هام طول ساعد & $r \cdot$ & طول تكيه كاه آرنج \\
\hline صدى هام فاصله آرنج تا آرنج & $4 V / q$ & فاصله بين دو تكيه كاه آرنج \\
\hline 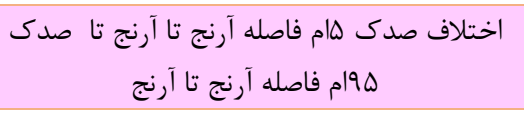 & $9 / 4$ & 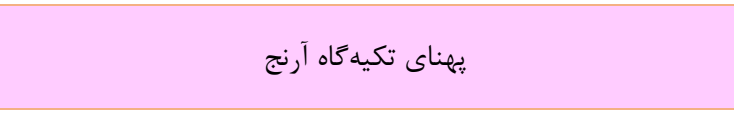 \\
\hline صدى هام تا صدك لهوام ارتفاع آرنج در حالت & $G \Delta / T-V F / F$ & ارتفاع پانل كنترل (از سطح كف اتاقى) \\
\hline 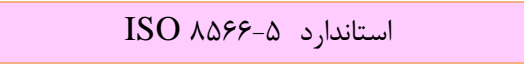 & ra & عرض پانل كنترل \\
\hline 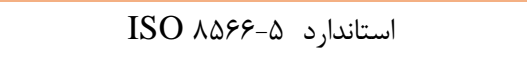 & \& & 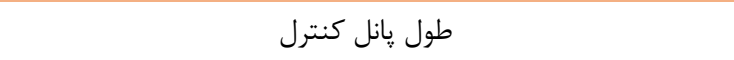 \\
\hline صدى هام تا صدى ه91م ارتفاع ارتفاع خشم در & $\| Q /|r G-F /|$ & ارتفاع مونيتور راهنما از كف اتاقى \\
\hline 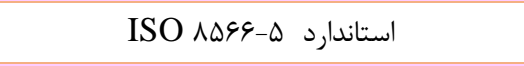 & 41 & دامنهُ حركت مونيتور راهنما (سيستم پايش الكترونيك)ج \\
\hline 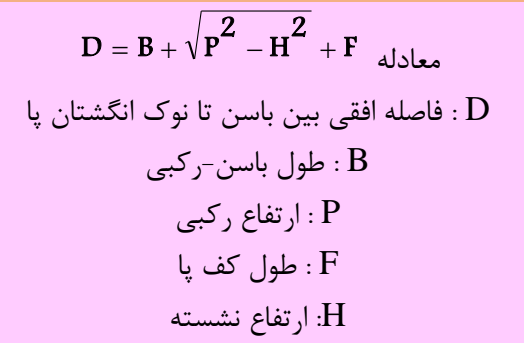 & $\wedge \vee / \Delta$ & فضاى موردنياز براى جلوى ڤا ( Pedaling) \\
\hline 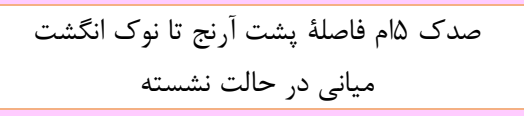 & $r V / Q$ & 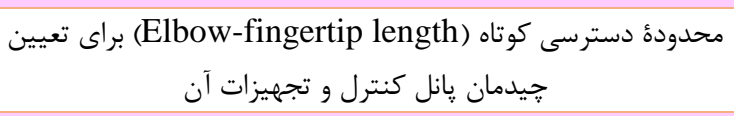 \\
\hline صدى هام فاصلهُ شانه تا نوك انَشت ميانى در & $\varepsilon V / r$ & 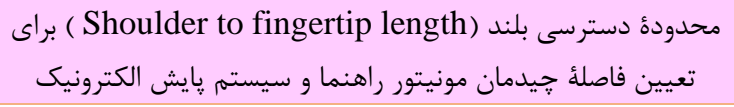 \\
\hline
\end{tabular}




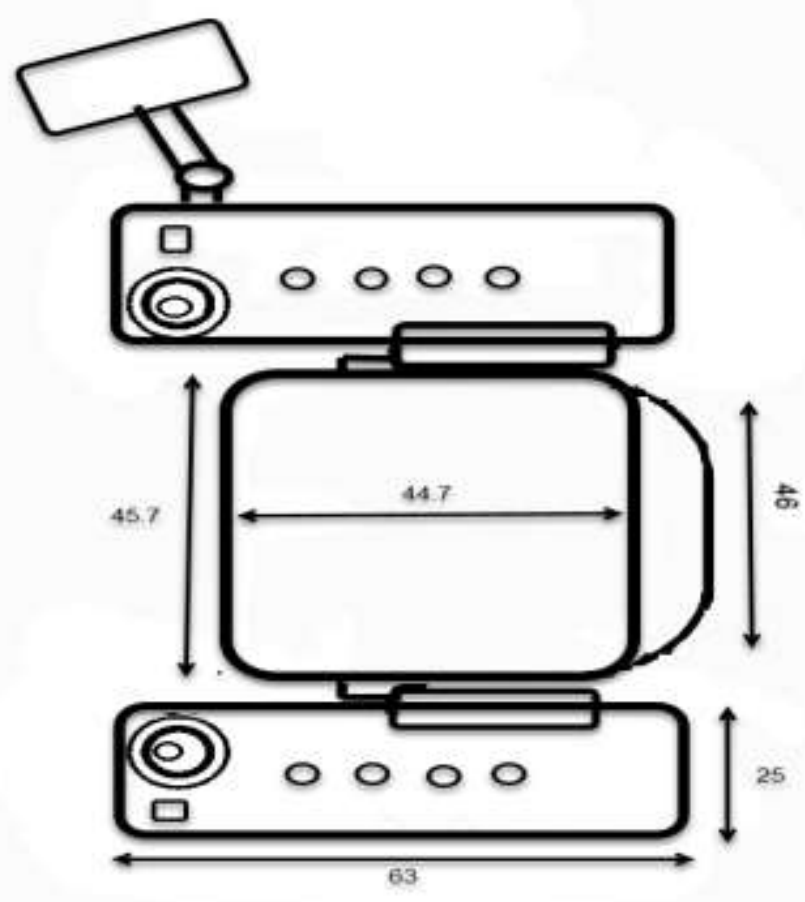

شكل r. ابعاد بازطراحى تجهيزات فضاى داخلى اتاقى
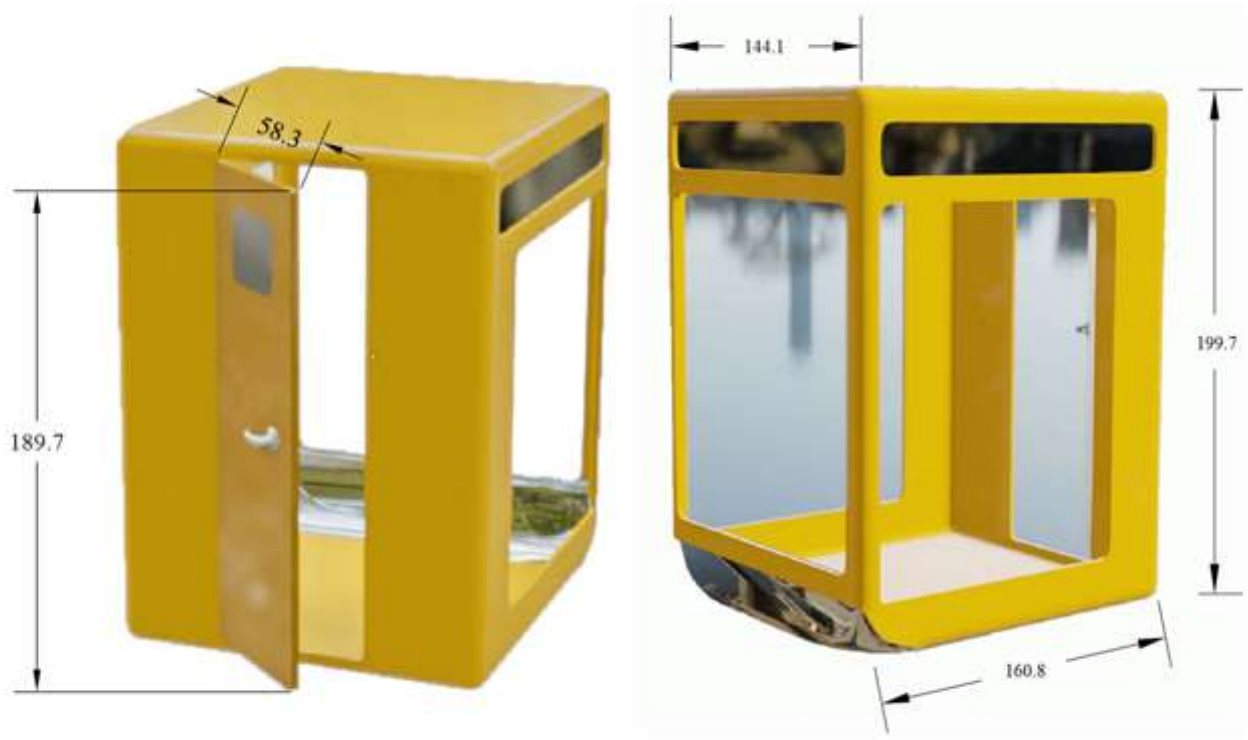

شكل ₹. نماى كلى و ابعاد اتاقى جرثقيل برجى طراحىشده براساس خروجى نرمافزار مدلسازى سهبعدى Blender

مداخله اركَونومى است. باتوجهبه اينكه تاكنون مطالعهاى در

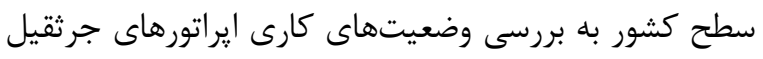

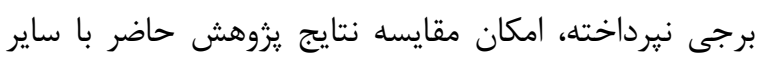

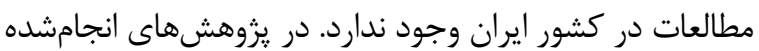

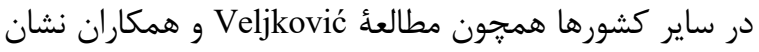
داد اكثر وضعيتهاى كارى و طراحى فضاى داخلى اتاقكهاى دماي جرثقيل موردبررسى در كشور صربستان در سطح غيرقابل فقبول
اين يزوهش با هدف ارزيابى ريسك اركونومى فعاليت

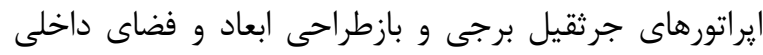

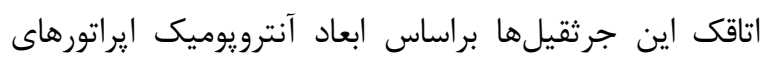

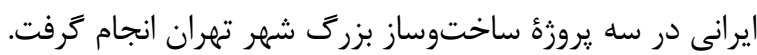

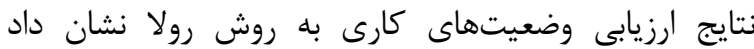

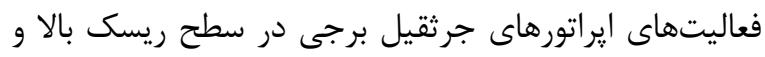

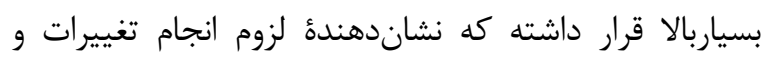




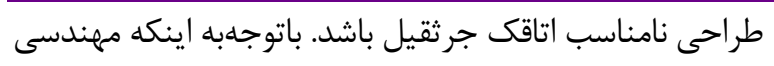

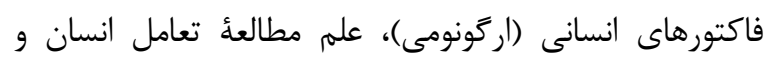

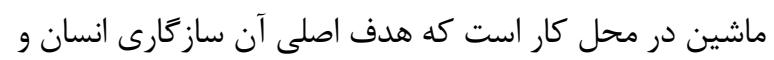

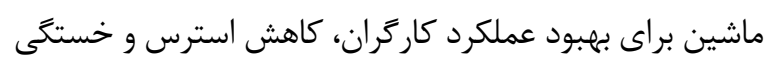

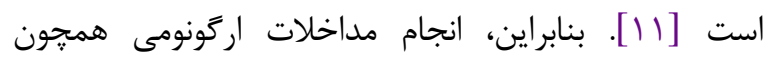
بازطراحى ايستخاه كارى ايراتورها براساس ابعاد آنتان آنترويومترى هدئ

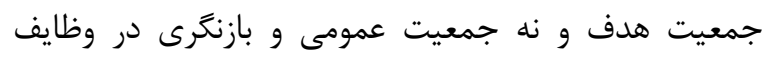

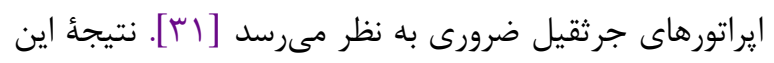

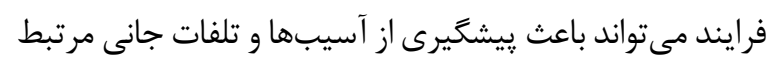

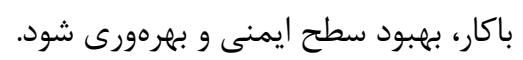

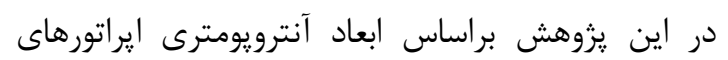

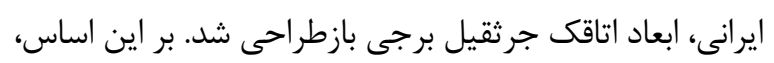

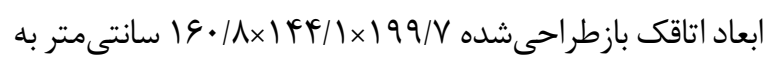

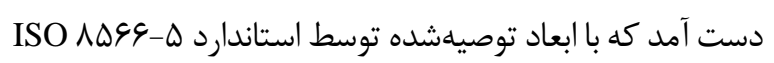

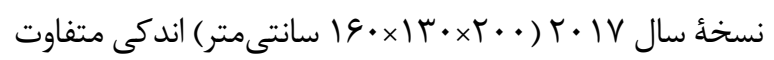

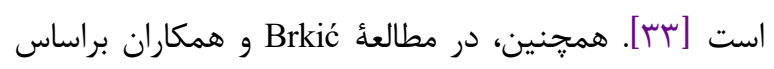

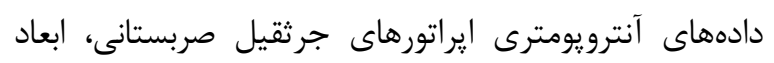

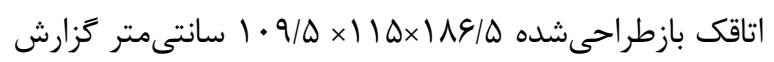

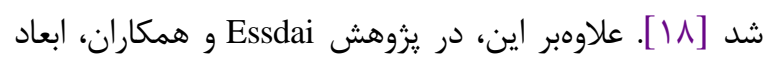

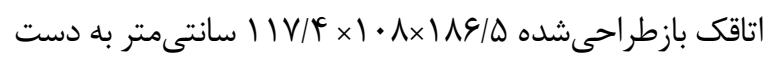

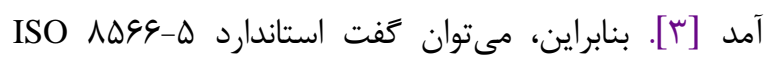

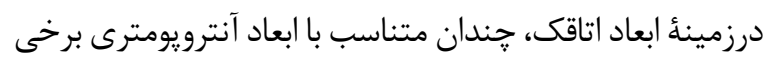

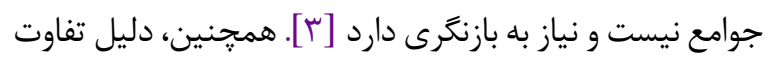

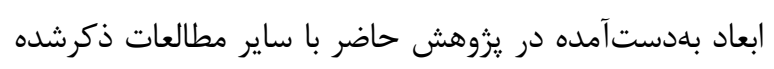

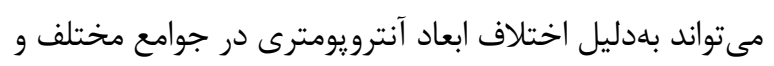

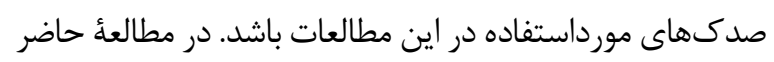

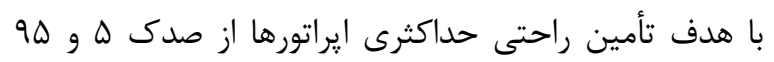

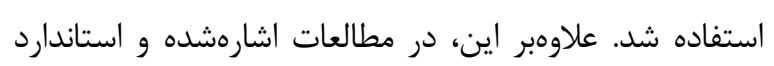

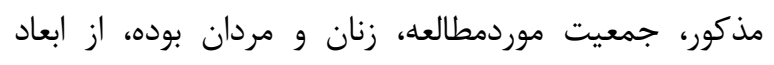
آنترويومترى زنان در تعيين برخى ابعاد اتاقك استفاده شده

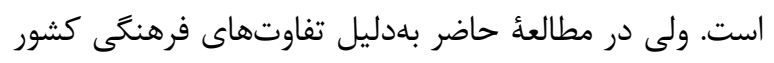

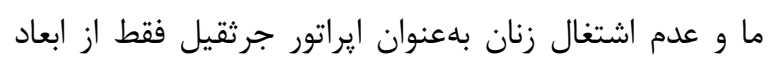

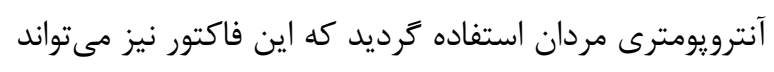

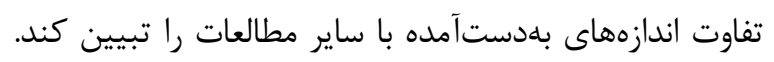

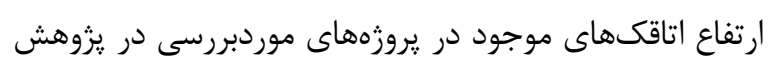

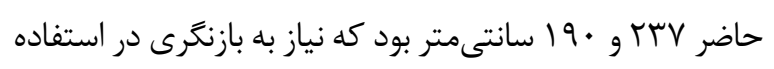

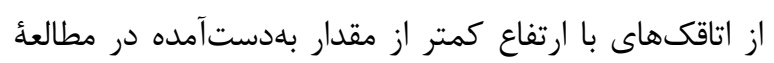

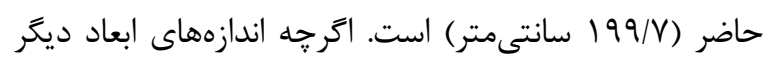

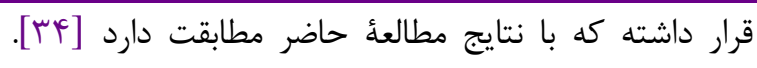

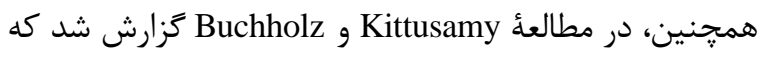
وضعيتهاى كارى (يوسجر) نامطلوب در ايراتورهاى ماشينهاى

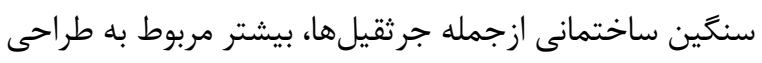

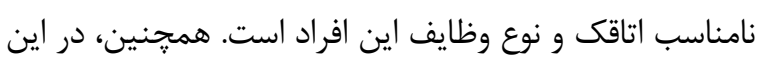

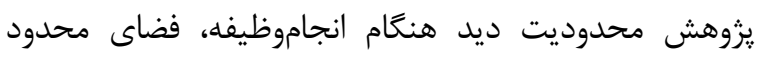

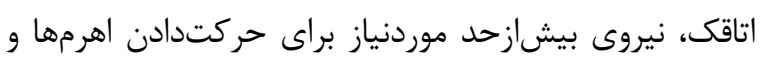

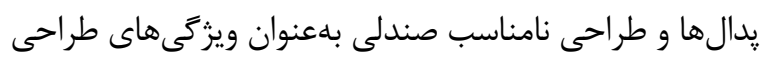

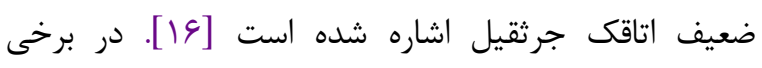

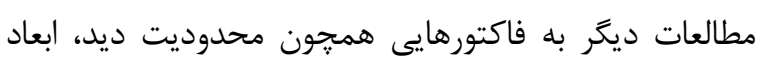

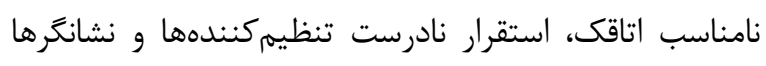

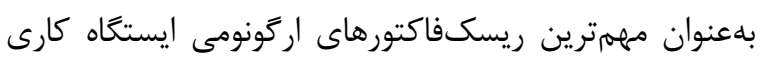

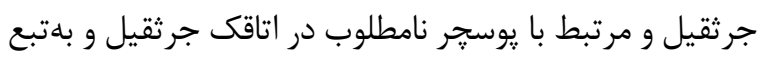

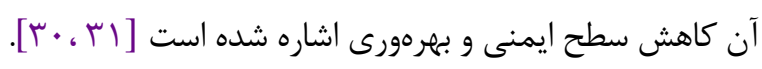

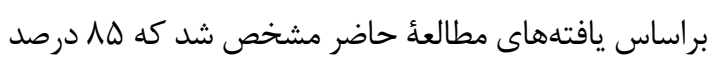

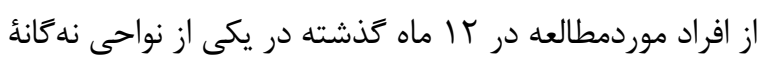

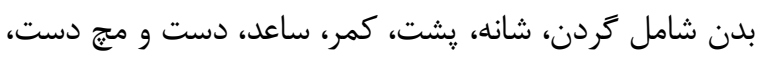

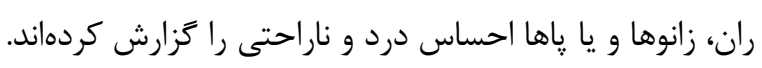

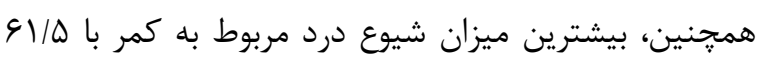

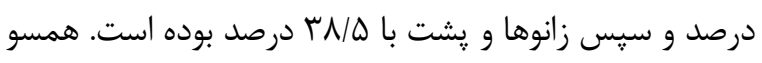

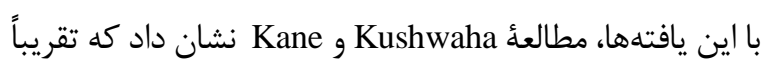

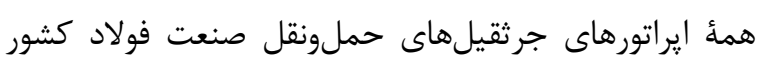

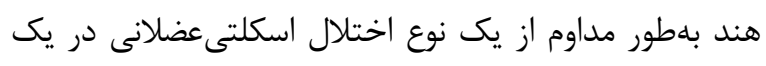

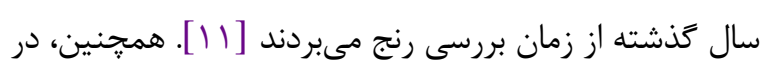

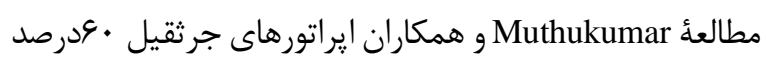

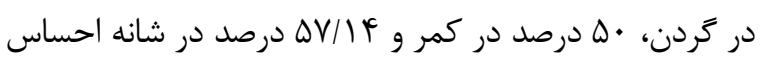

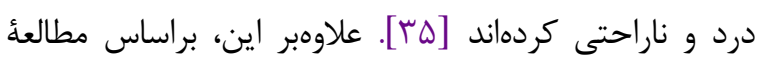
Bovenzi

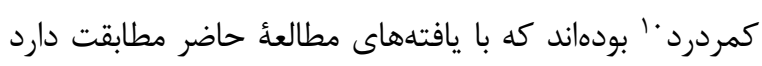

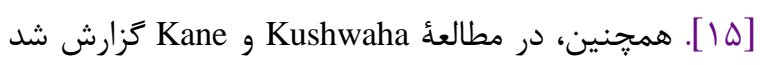
كه همأ ايراتورهاى جرثقيل در مطالئ موردبررسى از يكى نوع اختلال

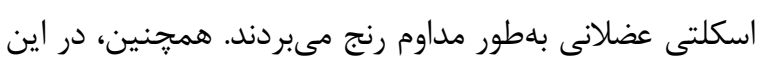

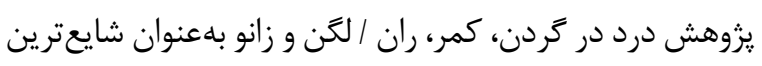

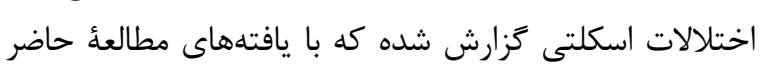

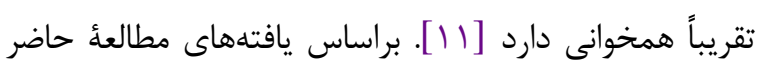

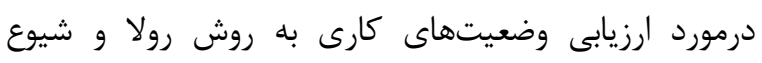

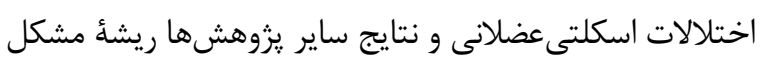

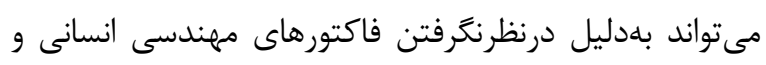


محمدرضا جنتى و همكاران | طراحى اتاقى جرثقيل برجى

ابعاد فضاى داخلى اتاقى استفاده شده است ولى در

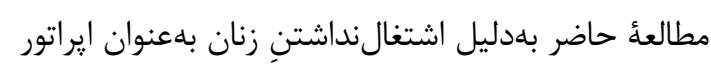

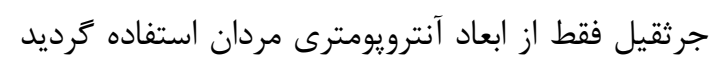

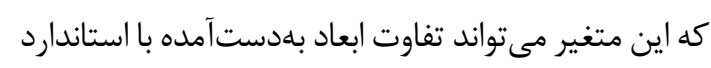
ذكرشده را تبيين كند.

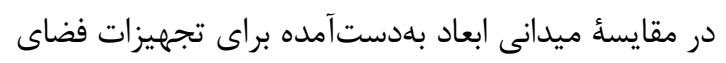

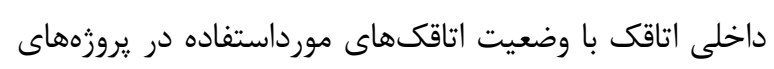

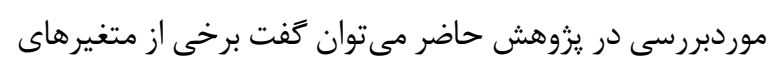

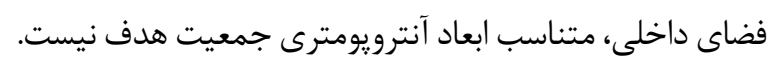

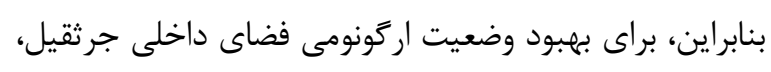

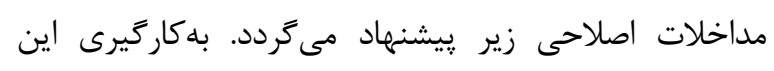

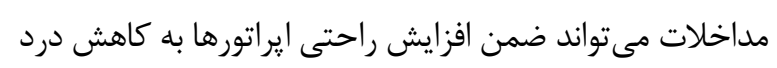

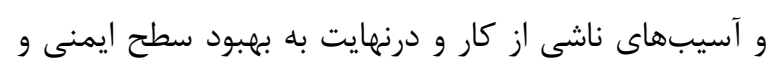

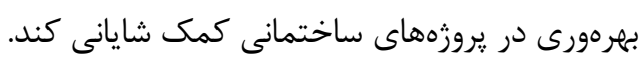
-

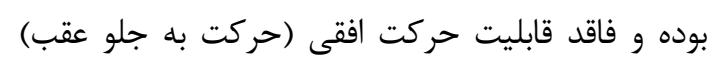

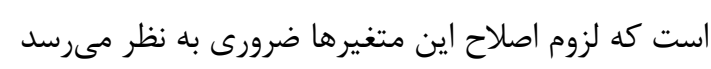

- ابعاد برخى صندلىها همجون عرض و عمق نشيمنگاه

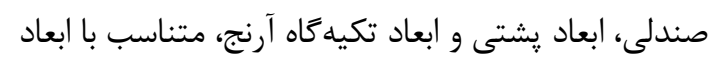

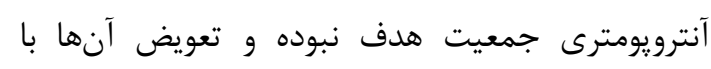

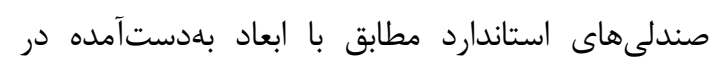
مطالعة حاضر توصيه مى مَردد.

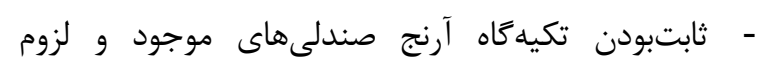

درنظركرفتن قابليت تنظيم ارتفاع براى تكيه كاه آرنج

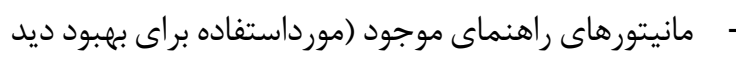

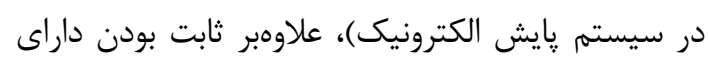

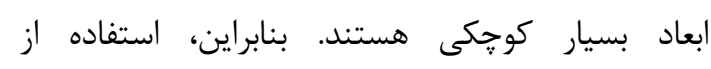
مانيتورهايى با ابعاد بزركتر و دارئي

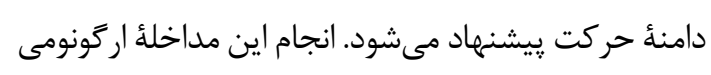

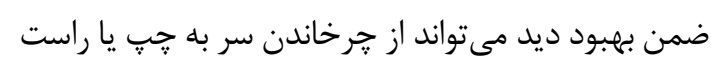

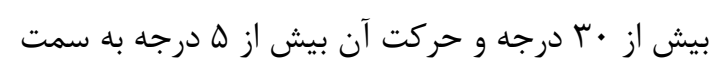

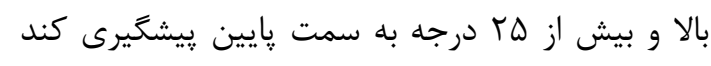

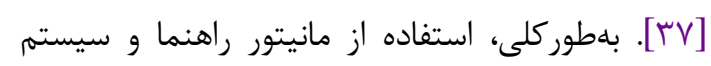

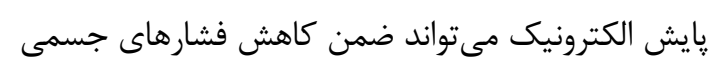

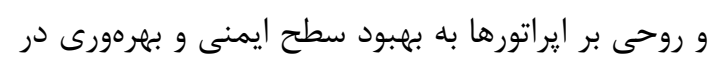

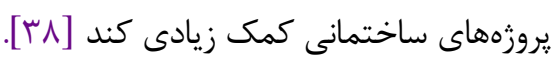

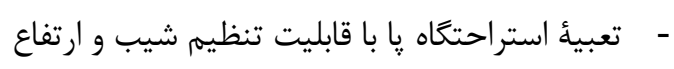

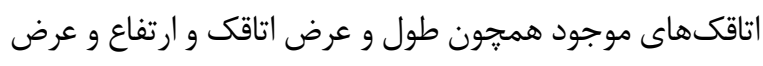

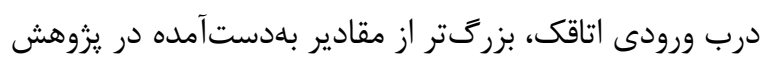

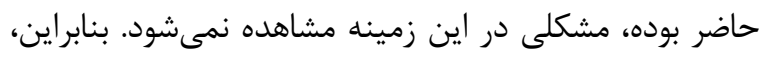

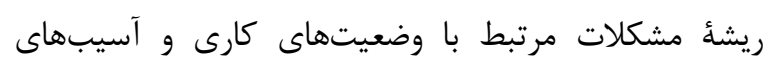

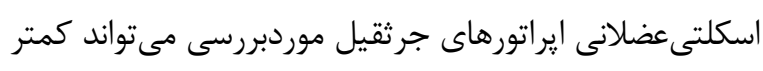

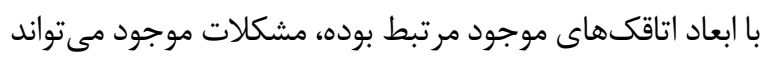

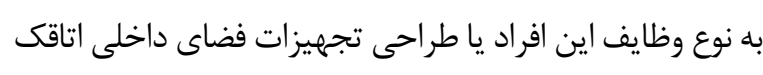

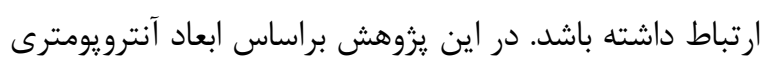

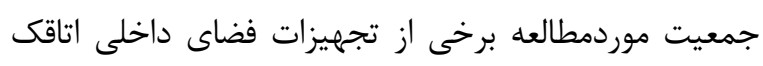

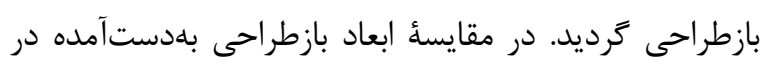

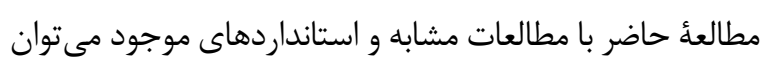

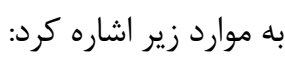

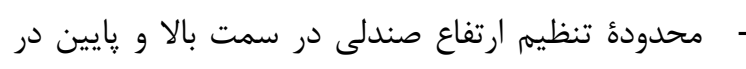

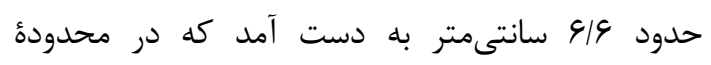

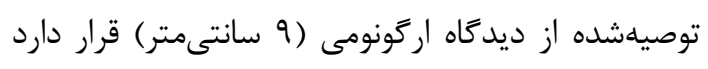
[111]

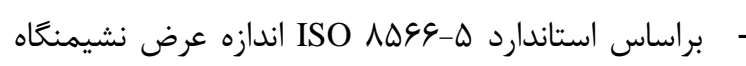

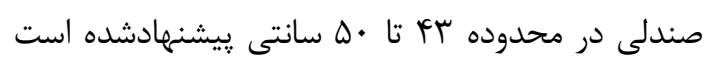

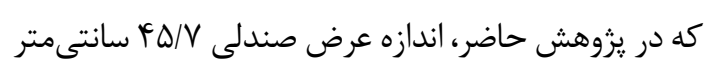

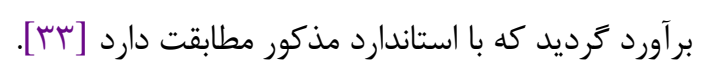

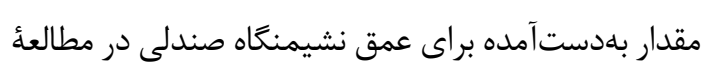

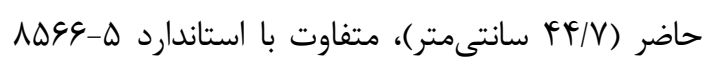

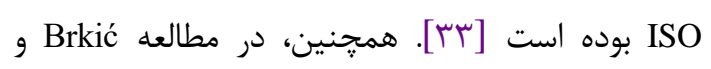

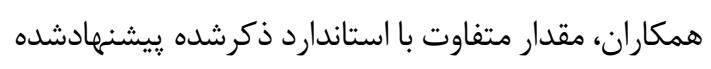
است كه با يافتههاى مطالعه حاضر همخوانى دارد [11 11].

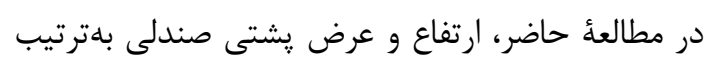
تو

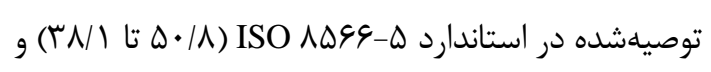

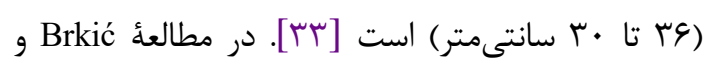

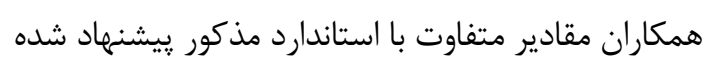

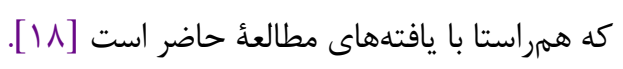

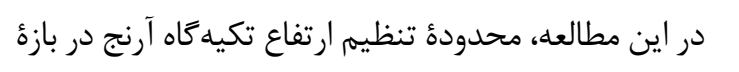

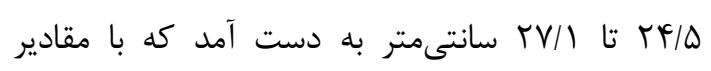

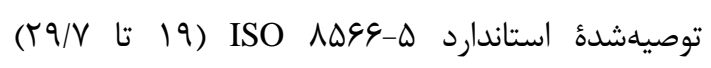

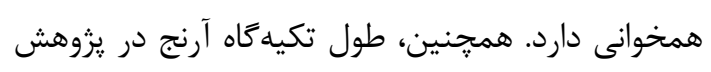

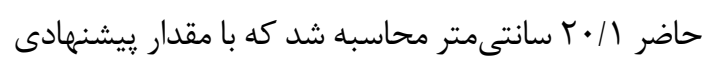

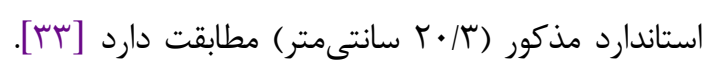

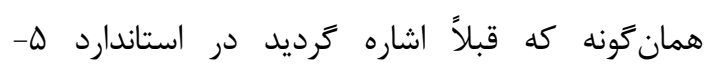

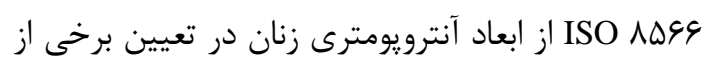


نتيجه كيرى

براساس نتايج مطالعه از ديدگًاه ارزيابى ريسك ارگونومى، فعاليتهاى ايراتورهاى جرثقيل برجى در سطح ريسك بالا قرار داشتند و درصد شيوع اختلالات اسكلتى عضلانى در بين آنها

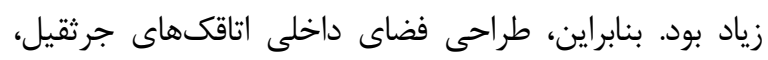
نيازهاى ايراتور را برآورده نمى كند و بـايهى باركيرى مداخلات اصلاحى و بازطراحى مجدد، جهت افزايش تطابق بين انسان و ورون

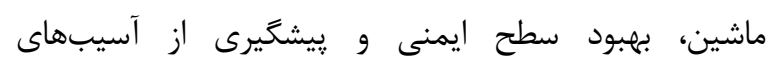
اسكلتى عضلانى ضرورى به نظر مىرسد.

\section{تقدير و تشكر}

اين مقاله بركرفته از طرح تحقيقاتى مصوب كميتٔ تحقيقات دانشجويى دانشگاه علوميزشكى سمنان است. نويسندكان مقاله بر خود لازم مى ندانند از كميتهٔ تحقيقاتى

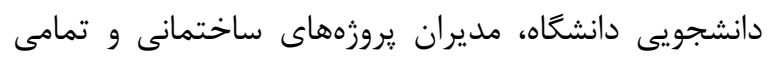
مشاركت كنندكان در اين مطالعه تشكر و قدردانى كنند. تعارض منافع بين نويسندگان هيج گونه تعارضى در منافع وجود ندارد. منابع مالى منابع مالى اين مطالعه توسط نويسندكان تامين شده است.

\section{References}

1. Labor B. Employed Persons by Detailed Industry, Sex, Race, and Hispanic or Latino Ethnicity, 2012. Bureau Lab Stat. 2013a.; 2013.

2. Labor B. Census of Fatal Occupational Injuries Summary, 2012. Bureau Lab Stat; 2013.

3. Essdai A, Spasojević Brkić VK, Golubović T, Brkić A, Popović V. Crane cabins' interior space multivariate anthropometric modeling. Work. 2018; 59(4):557-70. [DOI:10.3233/WOR-182706] [PMID]

4. Lee UK, Kang KI, Kim GH, Cho HH. Improving tower crane productivity using wireless technology. Comp-Aid Civil Infrastruct Engin. 2006; 21(8):594604. [DOI:10.1111/j.1467-8667.2006.00459.x]

5. Raviv G, Fishbain B, Shapira A. Analyzing risk factors in crane-related near-miss and accident reports. Safety Sci. 2017; 91:192-205. [DOI:10.1016/i.ssci.2016.08.022]

6. Neitzel RL, Seixas NS, Ren KK. A review of crane safety in the construction industry. Appl Occup Envir Hygiene. 2001; B16(12):1106-17. [DOI:10.1080/10473220127411] [PMID]
يشتى اكثر صندلىهاى موجود ثابت است و بايد امكان تغيير زاويةٌ يشتى در محدوده س تا V درجه در نظر گرفته شود [11] براى برخى از نشيمنعاههاى صندلىهاى موجود بايد لبئ. آبشارى " در نظر عرفته شود [عب]. اين يزوهش همانند مطالعات ديخر محدوديتهايى داشت. در مطالعهُ حاضر بهعنوان يك مطالعه اوليه، طراحى ايستخاه

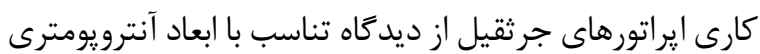

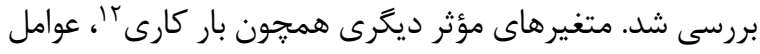
فيزيكى محيط كار همجون صدا، ارتعاش، روشنايى، درخشندگى، دما و رطوبت هوا، مىتوانند بر سطح راحتى و حتى اختلالات اسكلتى عضلانى اين افراد مؤثر باشد [ع ، ، 19]؛ بنابراين، بررسى اثر اين فاكتورها در كنار ابعاد آنترويومترى مىتواند در مطالعات آينده براى بهبود طراحى فضين فضى دایى داخلى

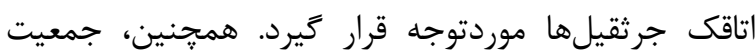
موردبررسى در يزوهش حاضر نسبتاً كم بود و به سه يروزئ بزرى ساختمانى در شهر تهران اختصاص داشته است. بنابراين،

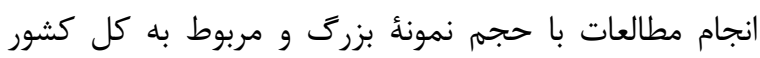
توصيه مىشود. در اين مطالعه، براى جمعآورى برخى دادهها از

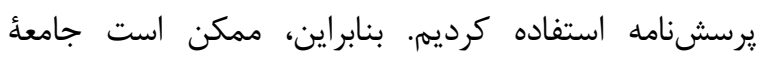

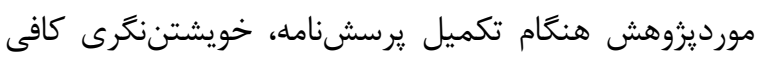
نداشته و مسئولانه به سؤالات پِاسخ نداده باشند.

7. Spasojević Brkić VK, Veljković ZA, Golubović T, Brkić AD, Kosić Šotić I. Workspace design for crane cabins applying a combined traditional approach and the Taguchi method for design of experiments. Int $\mathbf{J}$ Occup Safety Erg. 2016; 22(2):228-40. [DOI:10.1080/10803548.2015.1111713] [PMID]

8. Sertyesilisik B, Tunstall A, McLouglin J. An investigation of lifting operations on UK construction

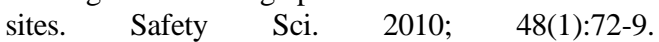
[DOI:10.1016/j.ssci.2009.06.001]

9. Yow P, Rooth R, Fry K. A report of the crane unit of the division of occupational safety and health. California: Division of Occupational Safety and Health California Department of Industrial Relations; 2000.

10. Swuste P. A 'normal accident' with a tower crane? An accident analysis conducted by the Dutch Safety Board. Safety Sci. 2013; 57:276-82. [DOI:10.1016/j.ssci.2013.03.002]

11. Kushwaha DK, Kane PV. Ergonomic assessment and workstation design of shipping crane cabin in steel industry. Int $\mathbf{J}$ Ind Erg. 2016;52:29-39. [DOI:10.1016/j.ergon.2015.08.003] 
12. Fung IW, Tam VW, Sing C, Tang K, Ogunlana SO. Psychological climate in occupational safety and health: the safety awareness of construction workers in South China. Int J Cons Manag. 2016; 16(4):31525. [DOI:10.1080/15623599.2016.1146114]

13. Beavers JE, Moore J, Rinehart R, Schriver W. Cranerelated fatalities in the construction industry. J Const Eng Manag. 2006; 132(9):901-10. [DOI:10.1061/(ASCE)0733-9364(2006)132:9(901)]

14. Shapira A, Elbaz A. Tower crane cycle times: case study of remote-control versus cab-control operation. J Const Eng Manag. 2014; 140(12):05014010. [DOI:10.1061/(ASCE)CO.1943-7862.0000904]

15. Bovenzi M, Pinto I, Stacchini N. Low back pain in port machinery operators. J Sound Vibrat. 2002; 253(1):3-20. [DOI:10.1006/jsvi.2001.4246]

16. Kittusamy NK, Buchholz B. Whole-body vibration and postural stress among operators of construction equipment: A literature review. J Safety Res. 2004; 35(3):255-61. [DOI:10.1016/j.jsr.2004.03.014] [PMID]

17. Committee H. Guidelines for using anthropometric data in product design: Human Fact Erg Soc; 2004.

18. Brkić VS, Klarin M, Brkić AD. Ergonomic design of crane cabin interior: The path to improved safety. Safety Sci. 2015; 73:43-51. [DOI:10.1016/j.ssci.2014.11.010]

19. Kamalinia M, Saraji GN, Kee D, Hosseini M, Choobineh A. Postural loading assessment in assembly workers of an Iranian telecommunication manufacturing company. Int J Occup Safety Erg. 2013; 19(2):311-9. [DOI:10.1080/10803548.2013.11076988] [PMID]

20. McAtamney L, Corlett EN. RULA: a survey method for the investigation of work-related upper limb disorders. Appl Erg. 1993; 24(2):91-9. [DOI:10.1016/0003-6870(93)90080-S]

21. Dockrell S, O'Grady E, Bennett K, Mullarkey C, Mc Connell R, Ruddy R, et al. An investigation of the reliability of Rapid Upper Limb Assessment (RULA) as a method of assessment of children's computing posture. Appl Erg. 2012; 43(3):632-6. [DOI:10.1016/j.apergo.2011.09.009] [PMID]

22. Levanon Y, Lerman Y, Gefen A, Ratzon NZ. Validity of the modified RULA for computer workers and reliability of one observation compared to six. Ergonomics. 2014; 57(12):1856-63. [DOI:10.1080/00140139.2014.952350] [PMID]

23. Ghasemkhani M, Azam K, Aten S. Evaluation of ergonomic postures of assembling unit workers by Rapid Upper Limb Assessment. Hakim Res J. 2007; 10(2):28-33.

24. Dickinson C, Campion K, Foster A, Newman S, O'rourke A, Thomas P. Questionnaire development: an examination of the Nordic Musculoskeletal Questionnaire. Appl Erg. 1992; 23(3):197-201. [DOI:10.1016/0003-6870(92)90225-K]

25. Dawson AP, Steele EJ, Hodges PW, Stewart S. Development and test-retest reliability of an extended version of the Nordic Musculoskeletal Questionnaire (NMQ-E): a screening instrument for musculoskeletal pain. J Pain. 2009; 10(5):517-26. [DOI:10.1016/j.jpain.2008.11.008] [PMID]

26. De Barros E, Alexandre NMC. Cross-cultural adaptation of the Nordic musculoskeletal questionnaire. Int Nurs Rev. 2003; 50(2):101-8. [DOI:10.1046/j.1466-7657.2003.00188.x] [PMID]
27. Dormohammadi A, Zarei E, Normohhammadi MR, Sarsangi V, Amjad SH, Asghari M. risk assessment of computer user upper musculoskeletal limb disorders in a power company by means of rula method and NMQ in 1390. J Sabzevar Uni Med Sci. 2014; 20(4):521-9.

28. European Committee for Standardization (CEN). Safety of machinery - Human body measurements Part 3: Anthropometric data (Standard No. EN 5473:1996+A1:2008). Brussels: European Committee for Standardization.

29. Human Factors and Ergonomics Society. HFES 300: Guidelines for Using Anthropometric Data in Product Design. California: Human Factors and Ergonomics Society; 2004.

30. Nordin F, Olsson S. Development of driver environment in crane cabin. MA thesis. Luleå: Luleå University of Technology; 2008.

31. Zunjic A, Brkic VS, Klarin M, Brkic A, Krstic D. Anthropometric assessment of crane cabins and recommendations for design: A case study. Work. 2015; 52(1):185-94. [DOI:10.3233/WOR-152042] [PMID]

32. Actuators (Standard No. EN 894-4:2010). Brussels, Belgium: CEN; 2010.

33. International Standards Organizatio, 2017. Cranes Cabins - Part 1-5. ISO 8566.

34. Veljković Z, Spasojević-Brkić V, Brkić A. Crane cabins' safety and ergonomics characteristics evaluation based on data collected in Sweden port. J Appl Eng Sci. 2015; 13(4):299-306. [DOI:10.5937/jaes13-9564]

35. Muthukumar K, Sankaranarayanasamy K, Ganguli A. Study on Discomfort in Mobile Crane Operation. Ace. 2017; 35:13.

36. Chandler F. Human Factors Engineering Guidelines For Overhead Cranes. 2001. Report No.: Report No. SC-YA-5436.

37. Barron PJ, Owende PM, McDonnell KP, Ward SM. A method for assessment of degradation of task visibility from operator cabins of field machines. Int $\mathbf{J}$ $\begin{array}{lll}\text { Indust } & \text { Erg. } & \text { 2005; }\end{array}$ [DOI:10.1016/j.ergon.2005.02.001]

38. Dondur N, Spasojević-Brkić V, Brkić A. Crane cabins with integrated visual systems for the detection and interpretation of environment-economic appraisal. J Appl Eng Sci. 2012; 10(4):191-6. [DOI:10.5937/jaes10-2516] 